\title{
Anthropology in the Museum Reflections on the curatorship of the Xikrin Collection
}

\author{
Fabiola A. Silva, Cesar Gordon
}

\begin{abstract}
This article reflects upon the curatorial management process of the Xikrin ethnographic collection and proposes the importance of anthropological interest in the deepening collaboration amongst anthropologists, indigenous peoples and museums, with particular attention to the anthropological study of ethnographic collections. This is true for the anthropological study of objects (and their various meanings and interpretations by the social actors who utilize and appropriate them) and for the understanding of the formation and conservation of ethnographic collections (with their diverse motivations and contexts). Since this type of shared curatorial management style is only now spreading throughout Brazil, the experience is a timely opportunity to develop nuanced perspectives on the anthropological significance of ethnographic collections.
\end{abstract}

Keywords: museums, indigenous peoples, ethnographic collections, objects, material culture, knowledge and recognition

\section{Resumo}

Neste artigo pretendemos apresentar algumas reflexões em torno do processo curatorial da coleção etnográfica Xikrin, evidenciando as potencialidades das relações entre antropólogos, povos indígenas e museus, especialmente, no que se refere ao estudo antropológico das coleções etnográficas, tanto em termos da compreensão dos objetos (e de seus múltiplos níveis de significação para os diferentes sujeitos que deles se apropriam), quanto em termos do entendimento da formação e preservação das coleções etnográficas (com suas múltiplas motivações e contextos). Este tipo de curadoria compartilhada começa a se difundir em nosso país, de sorte que o relato dessa experiência é uma oportunidade de estimular estes novos olhares sobre as coleções etnográficas.

Palavras-chave: museus, povos indígenas, coleções etnográficas, objetos, cultura material, conhecimento e reconhecimento 


\title{
Anthropology in the Museum Reflections on the curatorship of the Xikrin Collection
}

\author{
Fabiola A. Silva, Cesar Gordon
}

\section{Introduction}

This article describes the approach to the curatorial process of the Xikrin ethnographic collection in the Museu de Arqueologia e Etnologia (Archeological and Ethnological Museum) of the Universidade de São Paulo, São Paulo, SP Brazil, and analyzes the potential of these new relationships between anthropologists, indigenous peoples and museums, particularly for the anthropological study of ethnographic collections. The goal of the following reflections is to deepen the understanding of objects (and their various meanings and interpretations by the social actors who utilize and appropriate them) and for the understanding of the formation and conservation of ethnographic collections (with their diverse motivations and contexts). As the shared curatorial style is currently spreading throughout Brazil, our experience may help to foster new perspectives on the subject. On the one hand, the Xikrin Collection is a witness of a part of the history of Brazilian anthropology; on the other hand, it is a material representation of certain moments of history, the cultural trajectory and way of life of a Brazilian native population. We understand the collection as a combination of diverse perspectives and our task during the curatorial process has been to make these visible. Further, with the possible overlapping and fusing among these perspectives, we have made their mutual influences explicit. Part of the collection's curatorial process took place in collaboration with the Xikrin people whose insight and knowledge enriched the work by giving life to the anthropological objects and new meanings to the collection.

The article is divided into four sections. The first section consists of a brief historical sketch of the relationship between anthropology and museums within the international and Brazilian contexts. In the second section, the Xikrin collection is introduced and described (for more detailed 
information on the collection, refer to our previous work Silva \& Gordon (Orgs.), 2011). The third section deals with the curatorial process itself and gives an idea of the procedures and steps taken by the authors, specifically regarding the participation of the Xikrin Indians. The fourth section recounts the reflexive analysis that the Xikrin participants provided and focuses on typical cultural misunderstandings which, in our opinion, illustrate in a singular way the style of curatorship we intend to undertake, one that makes explicit the polemical, relational and disputed dimensions of the entire curatorial process.

\section{Museums and Anthropology}

Collections of ethnographic objects are fundamental to the formation and the history of the institution of the museum worldwide. Starting from the curiosity cabinets that made up private collections of cultural artifacts, flora and fauna specimens, fossils and minerals collected in the wake of European colonial expansion between the 17th and 18th centuries ${ }^{1}$, museums became places of conservation, investigation and exhibition of objects (Ribeiro \& van Velthem 1998; Nash \& Feinman (Eds) 2003; van Velthem 2012). The Brazilian case was no different and ethnographical collections date back to the 1818 establishment of the Royal Museum, initially specializing in agricultural plants (Kodama 2009). In its first issue in 1839, the Brazilian Historical and Geographic Institute (IHGB) published "Suggestions as to what the members of the Brazilian Historical Society should seek in the provinces to send to the society's headquarters in Rio de Janeiro" and asked for "information on the customs of the Indians, their religious habits, their civilization, their estimated population, their artifacts ...”. The Institute was also looking for "information on minerals, animals, fowls, birds, fish and other specimens, labeled, if possible, according to their scientific taxonomy...wood used for building, exotic plants... useful fruits, balms and oils, and their employment in medicine". After many years of debate, in 1847 the IHGB proposed the establishment of a Section on American Archeology

\footnotetext{
1 Several authors attribute the origin of museums and other modern anthropological institutions to Curiosity Cabinets. The Ashmolean Museum of Art and Archaeology at Oxford University was established in 1683 from donations of objects kept by John Tradescant and donated by Elias Ashmole to the University of Oxford in the UK (Fowler 2003:13).
} 
and Ethnography. In 1851 the new statute updated the institutional perspectives according to contemporary scientific progress and in its first clause announced that the IHGB had the "responsibility of collecting, classifying, publishing and archiving documents on the history and geography of the [Brazilian] Empire and on the archeology, ethnography and languages of its native peoples" (Ferreira \& Noelli 2009).

By the end of the $19^{\text {th }}$ century and the beginning of the $20^{\text {th }}$, Natural and Anthropology History museums put great effort into forming, studying and exhibiting collections of objects from nature as well as from native societies and cultures. In the United States, professional anthropology was born around museums, such as the National Museum, the Smithsonian Institute, the Peabody Museum of American Archeology and Ethnology (at Harvard University), the Field Museum (in Chicago), the American Museum of Natural History (Patterson, 2001). Even under the influence of the Boasian project, which, up to a certain point, helped transfer the center of anthropological practice from the museum to the university, the complementarity of ethnographic research and museumology remained. In fact, several scholars endeavored to map out new areas of research by developing comparative regional projects that were materialized in new ethnographic collections while they intensified studies within existing lines of research.

Within the Brazilian context and with regard to the formation and analysis of collections, the relationship between Anthropology and Museums was defined by a specific manner of practicing anthropology, which, in its turn, implied different collecting practices. The first Brazilian anthropologists were museum professionals and thus directly or indirectly responsible for the acquisition of the extant ethnographical collections current in the country's museums, such as, for instance, the Museu Nacional (National Museum) of Rio de Janeiro, the Museu Paulista (Museum of São Paulo), the Emilio Goeldi Museum in Belém (Pará) and the Museu de Arqueologia e Etnologia da Universidade de São Paulo (Archeological and Ethnological Museum of the University of São Paulo). The first phase of collection in Brazil, ranging between the last decades of the $19^{\text {th }}$ century and the first half of the $20^{\text {th }}$ century, was marked by studies on native populations. Anthropology was mainly related to the natural sciences in the context of encyclopedic and multidisciplinary research. Several collections of human remains were built parallel to ethnographic collections that were organized 
from a conservational point of view. During this period one of the main aims of museums was the collection and preservation of material testimonies to indigenous populations thought at that time to be close to extinction or cultural assimilation. As from the last quarter of the $19^{\text {th }}$ century, the most important figures in the Brazilian anthropological collectionism were Ladislau Neto, director of the Museu Nacional of Rio de Janeiro from 1870 to 1893; João Barbosa Rodrigues, who founded and supervised the Museu Botânico do Amazonas (Amazon Botanic Museum) from 1884 to 189o; Emílio August Goeldi, manager of the Museu Paraense (The State of Pará Museum) between 1891 and 1907; Hermann von Ihering, director of the Museu Paulista between 1894 and 1915; and Curt Nimuendajú who collected numberless objects produced by several indigenous peoples from different Brazilian regions under the aegis of national and international museums (Grupioni, 1998; Abreu, 2005; 2008; Ferreira, 2010). The beginnings of anthropological research on ethnographic objects deposited in museums may be characterized primarily by classification and descriptive work on collections and their organization by evolutionary, comparative or historical heuristics according to the researchers' theoretical interests (Collier \& Tschopik Jr. 2003 \& Fowler 2003). At this time, then, Brazil followed closely the trends of international anthropology and museology.

With the preeminence of British structural functionalism in the $1920 \mathrm{~s}$ and 1930s, interest in the study of ethnographic objects in museums was replaced by a focus on deep fieldwork and the functional logic of social life. Although an important factor for the descriptive and theoretical interests of the evolutionist and diffusionist traditions in anthropology, material culture did not retain its former importance and gave way to the type of sociological analysis envisaged by the British School. In fact, social anthropology was more concerned in studying social organization, kinship structures and political systems (Kuper 1973). In the United States, the new Boasian generation moved towards the psychological and mental dimensions of culture as Ruth Benedict's Configurationalism and the Culture and Personality School demonstrate (Stocking 1976). Motivated by the new research interests, anthropologists, as a rule, tended to abandon the study of artifacts in museums and in the field. Since Brazilian anthropology followed these international trends closely, the displacement of the discipline from museums to universities occurred there as well. 
There is no need to review the discipline's history. It is enough to point out that the greatest reduction of importance given to museums and their contents occurred during the 1960 s with the arrival of post-modernism which not only problematized field research and ethnographic writing but also strengthened the idea that museums were instruments of colonial glorification (Gordon \& Silva 2005). These ideas began to shift during the final decades of the $2 \mathrm{O}^{\text {th }}$ century which saw the surge of anthropological interest in the study of material culture. A series of reasons, external and internal to the discipline, caused a return to objects and museum collections in anthropological research, especially as they started to be understood analytically as mediators and materializations of diverse social relationships, agencies, subjectivities, knowledge, memories, that circulate in and help to manage different regimes of meaning and value within the most varied social, cultural and political contexts (Appadurai (ed.) 1986; Miller 1987; 2005; Thomas 1991; Gell 1998; Myers 2001; Fabian 2004; Pasztory 2005; Henare et al 2006; Santos Granero (ed) 2009). In fact, we are still in the middle of this renewed anthropology of objects (for more recent discussions, see Gonçalves 2005).

Divergent ways of conceptualizing ethnographic collections arrived later and were mainly motivated by new anthropological perspectives on the concepts of the museum and its collections. Furthermore, they were also stimulated by an understanding of the transformations which occurred between colonized peoples and these institutions within post-colonial conditions (Pearce (Ed.) 1999; Hallam \& Street (Eds.) 2000; Peers \& Brown (Eds) 2003; Barcelos Neto 2006; Fabian 2010; Broekhoven, Buijs \& Hovens (Eds) 2010; Silva \& Gordon (Orgs)2011). During a long period, the relationship between museums and source communities was asymmetrical since professional researchers were the protagonists or leading agents of knowledge on these sources. They based their curatorial practice only on Western scientific traditions and on preservationist presuppositions that viewed indigenous populations, their way of life and their cultures, as destined for extinction or cultural assimilation (Shelton 2000; Hallan 2000; Peers \& Brown 2003; Nicks 2003). However, such a relationship has recently become more inclusive and symmetrical in many museological contexts as greater agency is practiced by indigenous populations, whose values and perspectives on sources and museums provide new and enriching perspectives (Peers \& Brown (Eds) 2003; Broekhoven, Buijs \& Hovens (Eds) 2010; Silva \& Gordon (Orgs) 2011). 
It is highly interesting to note that during recent years several studies have investigated the contexts in which these collections were formed, taking into account the historical, social and cultural milieux of the collecting process, the collectors' motivations and their management of the collections over a long period of time. Studies have shown that collections are not necessarily formed intentionally. Some scholars purposely form collections, which thus have more structure and adhere more tightly to certain themes, types of objects and chronology. Non-intentional collections, on the other hand, are those formed without previous planning. It may occur that these collections may have been perceived as such by their collectors after a certain lapse of time. In this case, collecting may become a conscious action and certain objects may be collected for a specific goal. Another important aspect that should be taken into consideration is that when the motives for the formation of collections are debated, they reflect the occupation of the organizer. The collected items are also vectors that express a certain lived experience (Belk 1999). Collections may have been formed because the collectors wanted to demonstrate their relationship with certain people or preserve certain objects as history and give continuity to a determined experience or achievement (Formaneck 1999). In this case, the objects accumulate yet another meaning which enrich their interpretive possibilities and potential angles of research (Pearce 1999a; 1999b; Grupioni, 1998; Nash \& Feinman (Eds), 2003; Hallam, 2000 \& Shelton, 2000).

\section{The Mebêngôkre-Xikrin ethnographic collection}

In our view, a collection of ethnographic objects allows diverse interpretations. It is, after all, the result of a certain collector's perspective and decisions, embedded within a complex context of interaction with those who produced the objects at a specific historical moment. At the same time, it is made up of objects with their own specific courses and agencies, with multiple meanings and interpretations including those attributed by the cultural systems that produced them and the museological institutions with their own paradigms of classification and analysis. The plurality of interpretations necessitates multiple levels of analysis that can only be performed by many different actors contributing their perspectives, and thus requiring the participation of various specialists, both academic and indigenous (Silva \& Gordon 2011a). 
The Mebêngôkre-Xikrin ethnographic collection was donated to the Museu de Arqueologia e Etnologia da Uiversidade de São Paulo (MAE-USP) in July 2001. The collection was formed by the anthropologist Lux Boelitz Vidal during her thirty-year research among the Xikrin Mebêngôkre Indians, a thousand strong indigenous group living near the Carajás Mountain Range in the northern state of Pará, Brazil, linguistically and culturally similar to the Kayapó (who refer to themselves as the Mebêngôkre). Vidal started her ethnographic research among the Xikrin in the late 196os when only scanty information was available. Her doctoral thesis was the result of her cumulative research, which in turn, was published as Morte e Vida de uma População Indígena [Life and death of an indigenous population] (Vidal 1977), followed by a series of other publications on the same subject. However, Vidal's relationship with the Xikrin went beyond purely academic interest. She became involved in advocacy for the Xikrin and participated actively in the demarcation process of the Xikrin Indigenous Land of the Cateté in the 1980s, as well as in a non-governmental organization for the protection of Indigenous persons. She acted consulting anthropologist during the planning of the Projeto Grande Carajás (Project Grand Carajás) of the Vale do Rio Doce mining company, with tremendous social, political and economical impact on the southern region of the state of Pará and on the history of the Xikrin population (Gordon 2003; 2006). During her decades among the Xikrin, Vidal collected objects manufactured by the community, which she received as presents, exchanged or bought. The items were part and parcel of her academic activities and her life as an anthropologist. They were kept at her home, utilized as illustrations in her lectures and lent out for several expositions. They are currently kept at the MAE at the University of São Paulo.

The collection is composed of approximately 400 different and relatively well-preserved items. They comprise body ornaments made of bird feathers (bracelets, head-dresses, necklaces, breast plates, earrings and sashes), cotton fibers (bracelets, head-dresses, belts), straw (bracelets, belts, crowns), wood (lip ornament, ear expanders), animals' teeth and bone (necklaces), beads (necklaces, belts, sashes, wrist bands), seeds (belts, sashes, wrist bands, necklaces), shell (earrings, necklaces); musical instruments made from animals' nails (rattles), reeds (horns and pipes), gourds (maracas), straw (whistles), wooden weapons (cudgels), palm tree (arches and arrows), bamboo (arrows), straw, resin and fiber toys (small animals); utensils and 
bone tools (needles and scarification instruments), earthenware (spindles), seeds (spindles), animals' nails (scarification instruments), wood (scarifying comb, containers); woven items (carrying baskets, pocket-like baskets, caselike baskets, small baskets, hammocks, mats, manioc strainers, masks), and prime materials (feathers, seeds, vegetal fibers).

The collection was formed unintentionally and without any previous planning, as opposed to other collections at the MAE-USP that were intentionally shaped by collectors who ordered and purchased the items. According to Vidal, she obtained and kept the items without any intention of making a collection. In fact, they were acquired during her research work and through mutual relationships with the Xikrin. However, the anthropologist was always eager to register (mainly ethnographically rather than from a museological point of view) and preserve the objects for donation to a museum, as in fact occurred. It may be said that the collection has a double meaning: 1) as the product of several years' work among the Xikrin Indians, it may be interpreted as a witness of the history of Anthropology in Brazil, since it represents and contextualizes part of the ethnologist Lux Vidal's research; 2) it also represents cultural traces of the Jê people through the material expression of their life styles. It should be noted that several items in the collection have a detailed history recorded throughout the years in Vidal's written registers (Silva \& Gordon 2011b).

\section{The curatorial management process}

According to Prown (1999), the museological analysis of a collection's objects may be divided into three steps: description, deduction and speculation. The descriptive stage outlines the objects' most generic and physical aspects, such as, measurements, weight, materials used and the way they were manufactured (for instance, welded, stitched, glued etc). Decoration is evaluated and the objects' three-dimensional aspects are analyzed. The deductive stage consists of verifying the objects functionality and their relationship with their formal characteristics. At the speculation stage, the researcher tries to understand the objects cultural meaning and thes social context of their production, distribution, and use.

On the other hand, according to Pearce (1999; 1999b), when researchers investigate an artifact, they try to answer the following questions: What? 
How? Where? When? By whom? Why? Consequently she divides research into the material, environmental, historical and significant spheres. The combined understanding of these contexts sheds light on an object's interpretation. The material sphere comprises the constructive aspects of the object, its design and characteristics in terms of origin and technique. In this way, it is possibly to construct a preliminary inventory of descriptive and comparative features. In the case of environment, the object's relationship with available natural resources on production and collection sites is elaborated. Studies on the landscape and local resources should be undertaken for this purpose. Regarding the historical contextualization of the object, the researcher should try to recover information on the artisan that manufactured the object, its contextual usage, and the history of its collection and exhibition. For significance, the researcher should understand the object's social and symbolic role within the context of its production and usage.

As curators of the Xikrin Collection, the current authors adopted the above-mentioned museological methods for the study of the collection and the analysis and classification of ethnographic material produced by other researchers devoted to the study of ethnographic collections2. Further, the ethnographic experience and the scientific production of researchers who worked among the Xikrin3, the knowledge of museum professionals (stewards, photographers, archivists, technicians), the perspective of scholars on material culture from other areas of knowledge (archeologists and architects) and the insights gained from the collaboration of Xikrin individuals were added to the authors' efforts. From the beginning of the research, Wagner Souza e Silva, a professional photographer, assumed responsibility for all documentary reports. Having documented the whole curatorial process, he is co-author of the book Xikrin: uma coleção etnográfica [Xikrin: an ethnographical collection]. (Silva \& Gordon (orgs) 2011). A brief description of the process will be given below since the process as a whole has already been detailed in other publications (Gordon \& Silva 2005; Silva \& Gordon 2008; Silva \& Gordon(Orgs) 2011).

The first step consisted of an inventory, numbering, technical and morphological description and cataloguing of the objects. The objects were

\footnotetext{
2 Stewardship project was funded by FAPESP (2003/12316-o).

3 Researchers who collaborated in current investigation wrote monographs on the same indigenous population (Vidal 1977; Gianinni 1991; Silva 2000; Cohn 2000; Gordon 2003; Paes 2006).
} 
Observation and design of Xikrin basketry (Photo by Wagner Souza e Silva)

photographed one by one and their main formal and technical characteristics emphasized. Initial photographic documentation aimed at constructing a database of images for future studies. All objects were registered on a standard card prepared by the Collection Management Department of the MAE (DAP) ${ }^{4}$. Besides providing information with regard to its place in the museum, the card also contains a description of the item with its morphological, functional and historical characteristics. It may also provide information on its state of conservation, on the researcher who collected and studied it, and on the available bibliography and the population that produced it. All descriptions and sketches of the items were undertaken after consulting works by Ribeiro (1980; 1985; 1987; 1988), van Velthem (1998), Frickel (1968), Chiara (1986) and Chiara \& Heath (1978).

Reviewing, correcting and revising the descriptions from information provided by researchers and by Xikrin Indians brought to São Paulo constituted the second step. Through a series of conferences, Lux Vidal gave information on the history and life cycle of several objects of the collection. Other

4 DAP - Departamento de Apoio à Pesquisa (Department for Research). Project of Research Infrastructure (FAPESP - Process 96/10598-3). 
researchers explained the cultural significance (social, ritual, economical) of different objects and the Xikrin Indians furnished the indigenous native terms, identified the objects' prime materials, production techniques, usage and meanings. They also gave details on rights of property, different styles of the artisans and histories and narratives of their origin. Both the curators and the Xikrin themselves documented all this work in audio and video.

\section{When the field is the museum}

Anthropologists normally travel to the regions where native populations they desire to study live. In contrast, in this case the Xikrins traveled to the "anthropologists' region" during the authors' curatorship. The museum became the ethnographic field. Ethnography was in the hands not only of the professional anthropologists but also of the Xikrin Indians who documented with their cameras everything they thought relevant to show to their peers in the ancestral village upon their return (for instance, MAE's resources and labs, the researchers' work, the supermarket shelves, the showcases full of beads in the Rua 25 de março in São Paulo).

The Xikrin chose two members of their community to go to São Paulo to participate in the curatorial process. Kengore Xikrin belonged to the social category of mature males with grandchildren (mebegnêt) and was considered a good artisan by the Xikrin, with vast experience and knowledge on the objects' manufacture, usage and meaning. He had actually worked with other anthropologists in the formation and stewardship of Xikrin ethnographic collections in a museum in Europes. The second Indian curator, Tamakwaré Xikrin, belonged to the category of male adults with many children but no grandchildren (mekrare tum). He was younger than Kengore, with a reasonable knowledge of material culture, and great importance within the community shown by his specific political involvement (he was brother to a chief of the male group and cousin of the village's elders). Since Tamakwaré had significant experience in political relationships between the Xikrin and non-Xicrin, his participation lent political legitimacy to the enterprise.

The curatorial work started with a visit to the MAE's archives and deposit

5 Kengore Xikrin had already worked in the curatorship of Xikrin objects together with René Fuerst, a researcher of the Xikrin people, affiliated with the Musée d'Ethnographie de la Ville de Genéve (Fuerst 2006). 


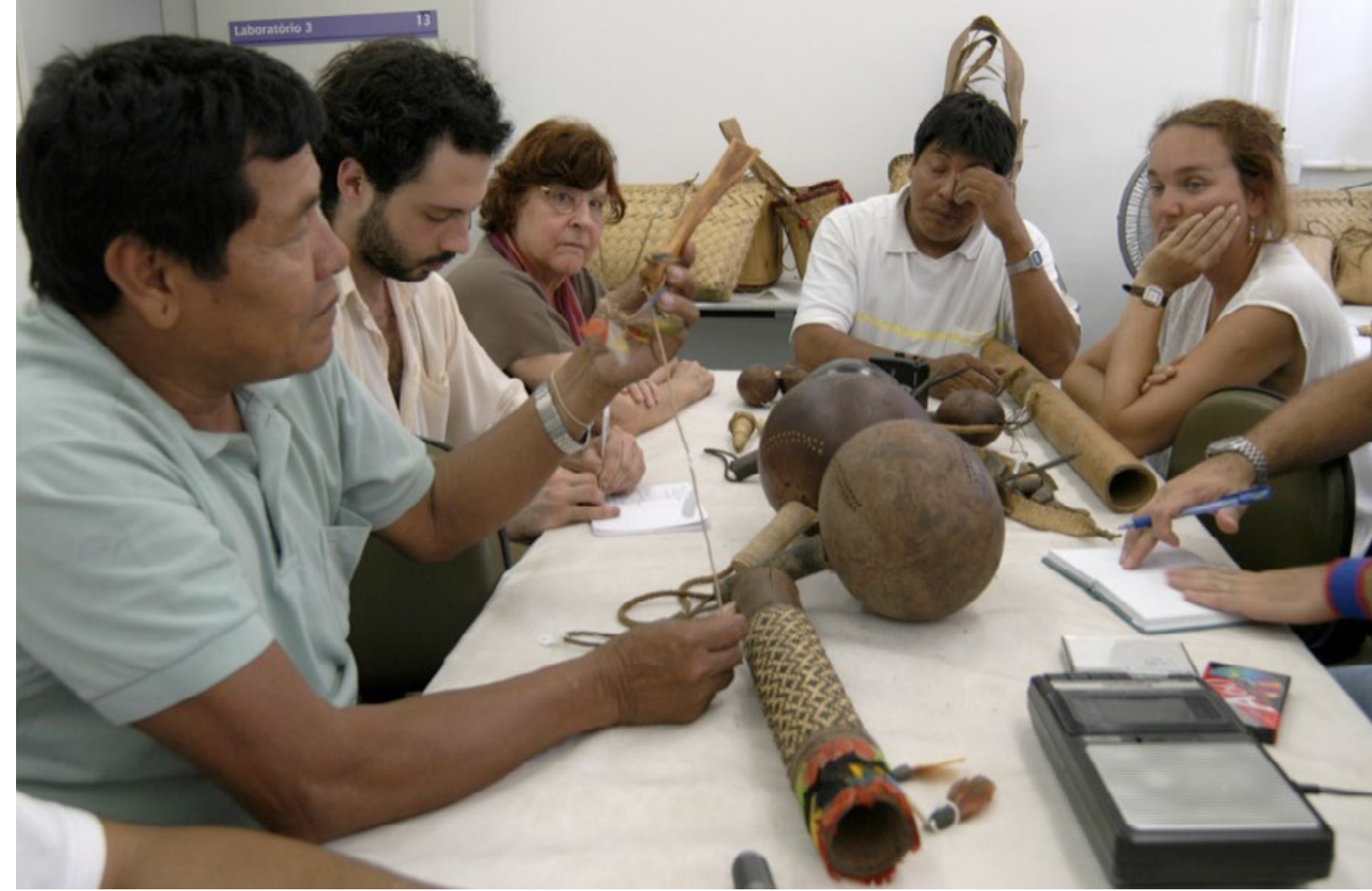

Study and documentation of the objects by the research team (Photo by Wagner Souza e Silva)

(Reserva Técnica). During the one-day visit, the Xikrin saw how objects from different ethnic groups were stored in the cabinets. They could specifically identify Xikrin and Mebêngôkre items that made up most of the deposit and which was their main interest. Disdain was their first reaction, as the Xikrins' attitude usually is (a sense of humor not unmixed with sarcasm), when they saw the drawers full of old artifacts. They remarked they were astonished that we kept all those old objects which belonged to people already dead, that it was better to throw everything away and that it would be more interesting to keep only the feathers and plumes for the manufacture of new items. In fact, it seemed to them that our keeping such old and decrepit items in the Deposit was the result of some type of morbidity on the part of the white Brazilians (or kuben, which is the mebêngokre native term for white brazilians and for non-Xikrin people in general). It is customary for the Xikrin to bury a person's material belongings together with the body itself. According to the Xikrin, personal objects are part of the person and invested with his or her subjectivity or agency. They may actually bear part of the dead persons' spirit (which is usually expressed by the mebêngokre word mekaron) and may eventually be transformed into dangerous pathogenic vectors. They 
were really astonished that we had made it a point to store so many different sorts of cultural objects manufactured by the Xikrin people and other items of diverse indigenous populations. However, after these first impressions, the two Xikrin men started to show some interest in the collection. By the end of the day they suggested that it was a good idea to collect and preserve some objects in the museum, especially those that were no longer manufactured in the village. For better or for worse, it was worthwhile to preserve that part of their history enclosed within the museum's drawers.

During the days that followed the visit to the Deposit, the Xikrin representatives assisted the authors in the curatorial processes in the strict sense of the term. This comprised a revision of the initial classification of the objects in the collection during which the two Xikrin participated willingly, patiently and even enthusiastically. We met in the Laboratório de Etnologia (Ethnology Laboratory) for the following ten days with several researchers, students and staff of the museum during the first stage of our work ${ }^{6}$. Daily work consisted of selecting a set of objects on which the Xikrin and researchers could speak and discuss with regard to their material features, techniques, usages and cultural meanings. The researchers first presented their knowledge of the objects and then the two Xikrin representatives confirmed or dismissed the information presented. They would correct and complement data and settle doubts on the prime matter used, utilization, names and the objects' manufacturers.

It should be noted that during the whole curatorship work the Xikrin thought and spoke freely on any and all objects in the collections. They highlighted the difference between the objects which were considered beautiful and correct (mejx, kumrenx) and others that were considered ugly (punure), fake or sham (kajgó) or pseudo-original imitations ( $k a^{\prime} a ̂ k$ ). Additionally, other objects reminded them of personal experiences as in the case of certain types of weaving which had been produced by Bep Karoti - a late but important Xikrin chief who is still remembered as a highly sophisticated artisan. Some objects caused unease while others caused admiration. Some were considered dangerous, like the breast decoration made of the Crax curassow's (mutum) head

6 Besides Tamakware and Kengore Kirin, there were: Researchers (Lux B. Vidal, Cesar Gordon, Fabíola Andréa Silva, Clarice Cohn, Francisco Paes, Isabelle Vidal Giannini, Ester Castro); students (Bruno Marcos Moraes, Daniel Tibério Luz, Chen Chih Cheng); technicians (Gedley Belchior Braga, Sandra Lacerda, Regivaldo); photographer (Wagner Souza e Silva). 


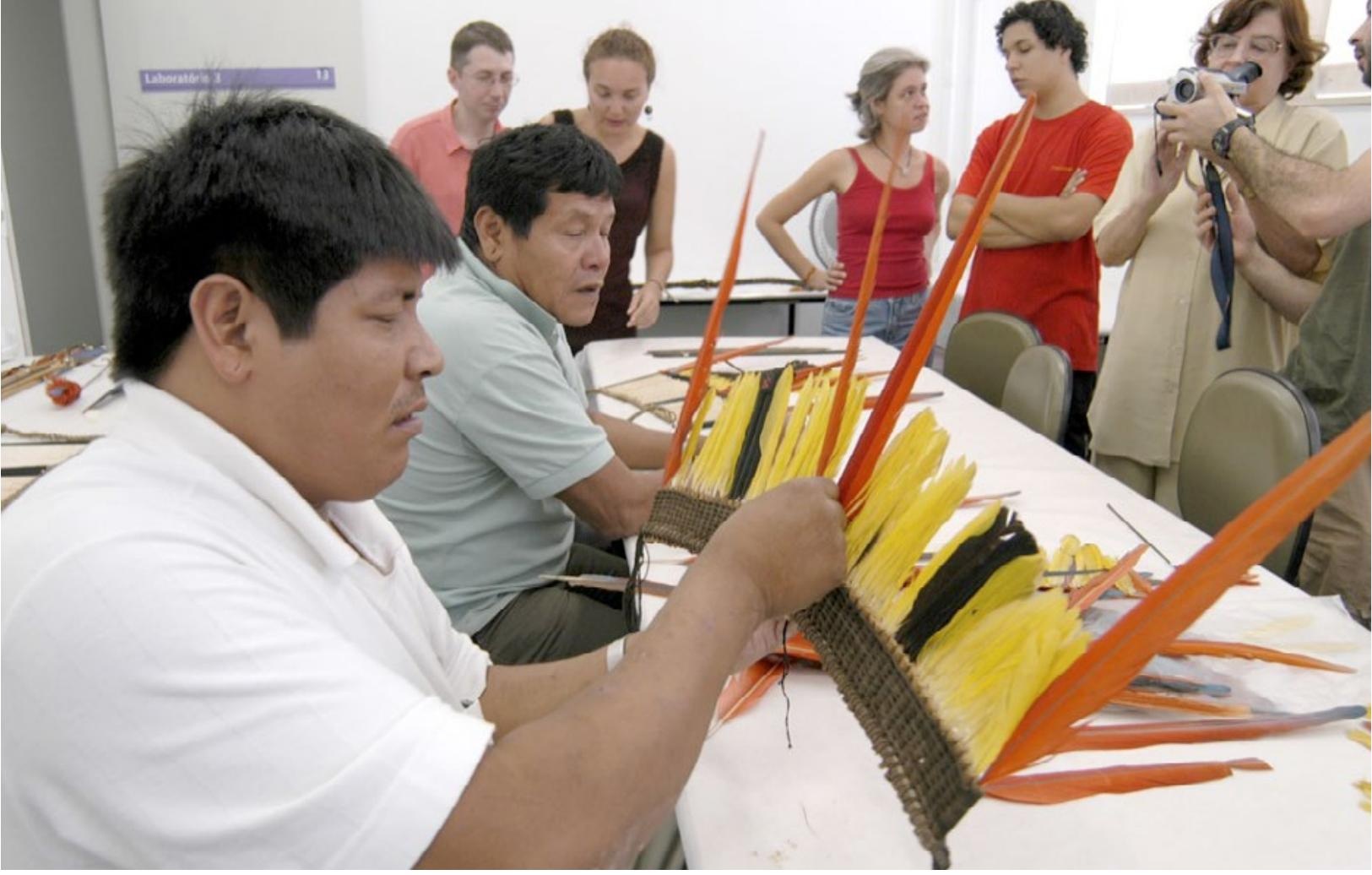

The Xikrin examine the pieces and restore certain items (Photo by Wagner Souza e Silva)

skin. And others were no longer manufactured in the village, like the scarification instruments made from the claws of the harpy eagle (harpia/gavião real). Other items, especially plume ornaments, were identified as the property or wealth (kukradjà) of certain persons or groups of individuals (Gordon 2011).

It should also be underscored that the Xikrin assembled some objects and repaired others, such as the feather ornaments and the rattles made from tapir nails. One of the most interesting, albeit somewhat tense, moments in the curatorial process occurred when the two Xikrin started to disassemble one of the parts of a magnificent plume ornament (krokoktire) (they slightly damaged it in the end), which, in our opinion, had great aesthetic, historical and ethnographical value; a masterpiece of the collection. According to the Xikrin, because the headdress had been restored and assembled incorrectly by a restorer hired by Lux Vidal some time ago and it should be repaired so that it would be once again not only beautiful but also correctly assembled. Working under the observation of the researchers and a concerned Vidal, the Xikrin transformed the object. In the opinion of the MAE curator, it became another object (Silva e Gordon 2008), although it was then the true/correct object, according to the Xikrin. Our position, as curators, was that it was transformed into a richer and more complex object. 
When Vidal commented later on the event, she slightly criticized our attitude:

"In my opinion, the Indians' participation was fundamental for the work done. However, a more structured discussion on the precise role of each within the curatorial process would have been worthwhile. Greater preparation and previous planning could have controlled better for the different variables that would result from the collaboration of the Xikrin with the MAE. What did you want from the Indians? Why were they required at that particular moment in the research? What should their contribution have been?" (Vidal apud Silva \& Gordon 2011b, p. 42).

Although we recognize that Vidal's critique was pertinent from her perspective and from the conservation stance in general, we would like to insist that the experience mentioned above evidences that anthropological practice in the museological context may (or should) also comprise the same uncertainty and imponderability as in the ethnographic fieldwork. In the field we are constantly mobilized by the indigenous persons' agency so that the anthropological endeavor would never be merely that of the anthropologists but also that of the 'natives'. Regardless of our theoretical and methodological choices and the definition of our research aims, it is always necessary to revise our investigative parameters and, should it be appropriate, transform our perspective vis-à-vis the perspective of the "Other." Precisely, if the leading role of Kengore Xikrin and Tamakwaré Xikrin in this specific episode left us motionless in the first place, on the other hand, and in the end, they provided more coherence to our proposal for shared curatorship. In this sense, as Lúcia Hussak van Velthem (2012:64) points out:

"The association of indigenous people with interpretative practices of collections would deconstruct the point of view of collectors and current museum techniques and would reconstruct a new perception. The collection of ethnographic objects as artifacts provided with functions and meanings would undergo a qualitative change since it would bear an evocative and mediating power. From this point of view, ethnographic objects would be collected less as remnants of traditional cultures and more as aids for discourse regarding identity of peoples long muted by those institutions".

We would like to insist that the above-mentioned episode, even as a 
misunderstanding and coupled to its polemic and contestable possibilities, strongly embodies the curatorial approach we would like to put into practice.

\section{Conclusion}

An ethnographical collection is formed by the selection and collection of objects that have a cultural meaning and value within a determined context. When the objects are displayed in a museum, they accumulate other meanings and are inserted into other value systems. They become objects that will be preserved, seen and studied by different persons who, in their turn, will provide them with other meanings according to their focus and experience. Pearce (1999b) states that museum objects are plurisemantic and as material reality their meanings will be re-elaborated and constantly revised and contested.

When campaigns in the defense of material and immaterial indigenous heritage become more widespread, research will be undertaken to document and record the populations' cultural manifestations (Gallois, 2006). Social and cultural transformations experienced by them will also show that the maintenance of ethnographic collections, principally in anthropological museums, is a highly important task not merely for the institutions' professionals but for the populations concerned. This is the motivation behind the emergence of indigenous initiatives for the construction of their own museums and collections. The Kuahí Museum for the Indigenous peoples of the Oiapoque (Vidal 2008), the Magüta Museum of the Ticuna Indians of the Solimões, the Mawo Museum of the Ikpeng Indians of the Xingu, the Museum of the Federation of Indigenous Organizations of the Rio Negro (FOIRN) in São Gabriel da Cachoeira and others are ground breaking. We are already far from the colonial and conservationist origins of ethnography. Current anthropological and museological perspectives must maintain a lively dialogue with indigenous perspectives on museums and collections.

Within the new modalities of museum curatorship, the embodiments of knowledge, requirements and demands of native peoples on ethnographic collections necessitate, in the first place, the acknowledgment of the importance that objects have in the process of the re-construction of identities and, in a wider sense, in their regimes of social reproduction. At the same time, there is the issue of the legitimacy of their claims on intellectual property and cultural 
ownership of the museum objects. There is the possibility of the subversion of power structures within the museum context when ethnographic collections leave their status as "trophies," or valuable fossils of fast vanishing worlds or prizes of Western expansion and morph into the loci of contact between different perspectives and world visions, the memories and the cultural heritage of living autonomous peoples living and producing dynamic cultures. Ethnographic museums do not merely say something about the past but are witnesses of the present and perhaps the future of indigenous peoples.

On one hand, researchers and museum professionals are challenged in their roles as specialists and within their scientific and institutional authority, and on the other, museological institutions acquire a space for multicultural reflections on the management of these collections. It is an opportunity for exchange and diversification of knowledge, a more symmetrical possibility for the meeting with the "Other" (Peers \& Brown 2003). The meeting will provide a space for negotiation between indigenous peoples and museums so that the former may achieve their goal of cultural revitalization and self-determination especially because many objects kept in museums are still present in the daily life of different peoples (Bolton 2003). When indigenous peoples go to museums, they make it clear that the items do not evoke a lost and nostalgic past since they continue in use many of these items in everyday life and they remind them of specific and personal histories, myths, songs, dances, people and events (Cruikshank 1998; Nicks 2003; Fienup-Riordan 2003; Silva \& Gordon 2011a).

The Xikrin ethnographic collection demonstrates the indigenous life style and, at the same time, reveals our relationships with the objects and the persons who created them. In spite of the fact that non-indigenous frameworks are increasingly becoming of fundamental importance to the Xikrin Indians, the latter are not willing to abandon completely their way of life. The Xikrin collection may thus be a witness of a certain period and of the transformations of indigenous life. This is its true importance. When we look at these objects, we see the Xikrin people of the past and the present. And what about the Xikrin? We hope that they look at these objects and see through them the everlasting Xikrin spirit.

English Translation: Thomas Bonnici / Peter Timothy Cahill Accepted for publication on February 22, 2013 


\section{Xikrin Collection}

selected pieces

Photos by Wagner Souza e Silva

MAE-USP, 2011 


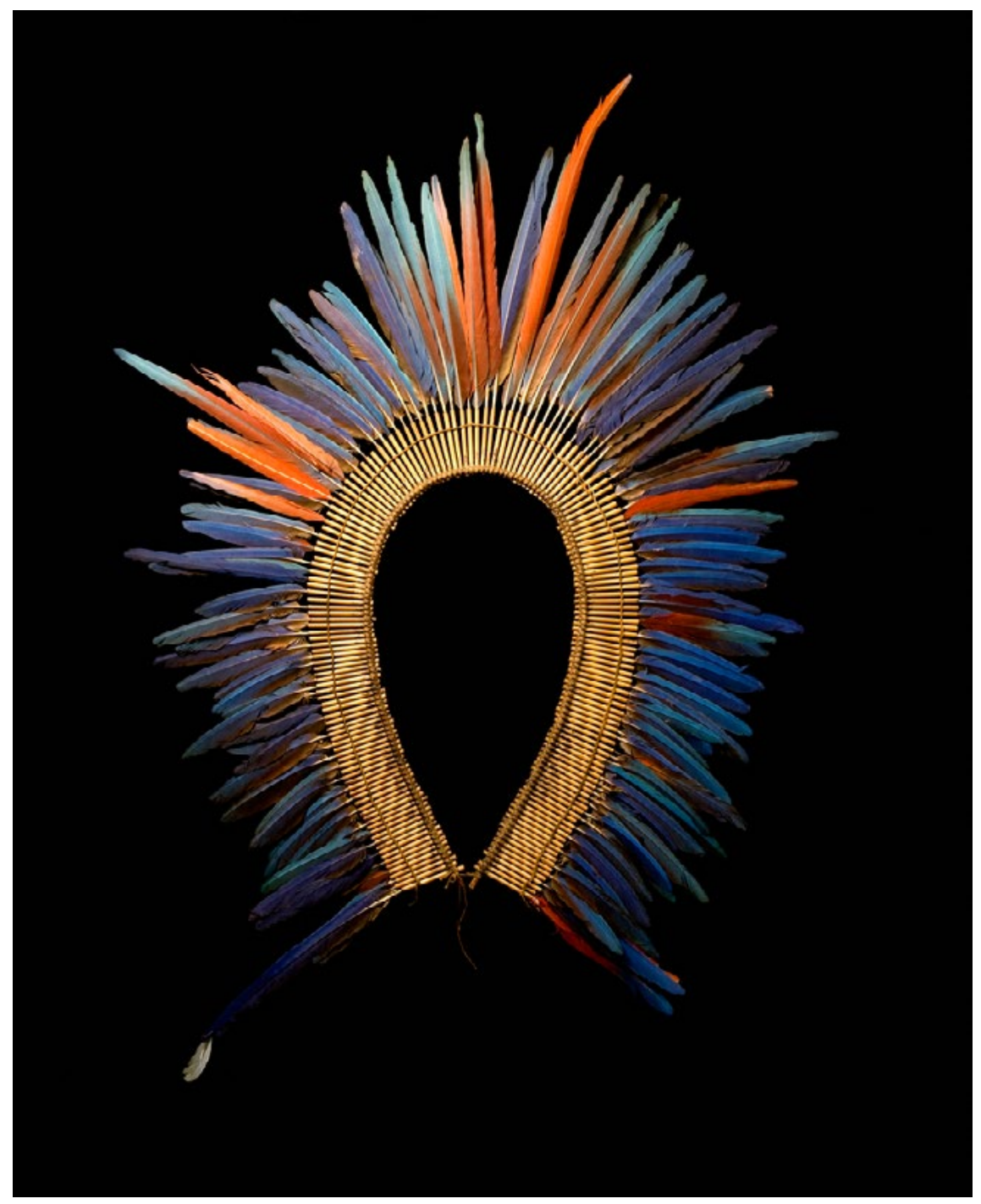

Large occipital circular headpiece (Àkparidjê rajx) 


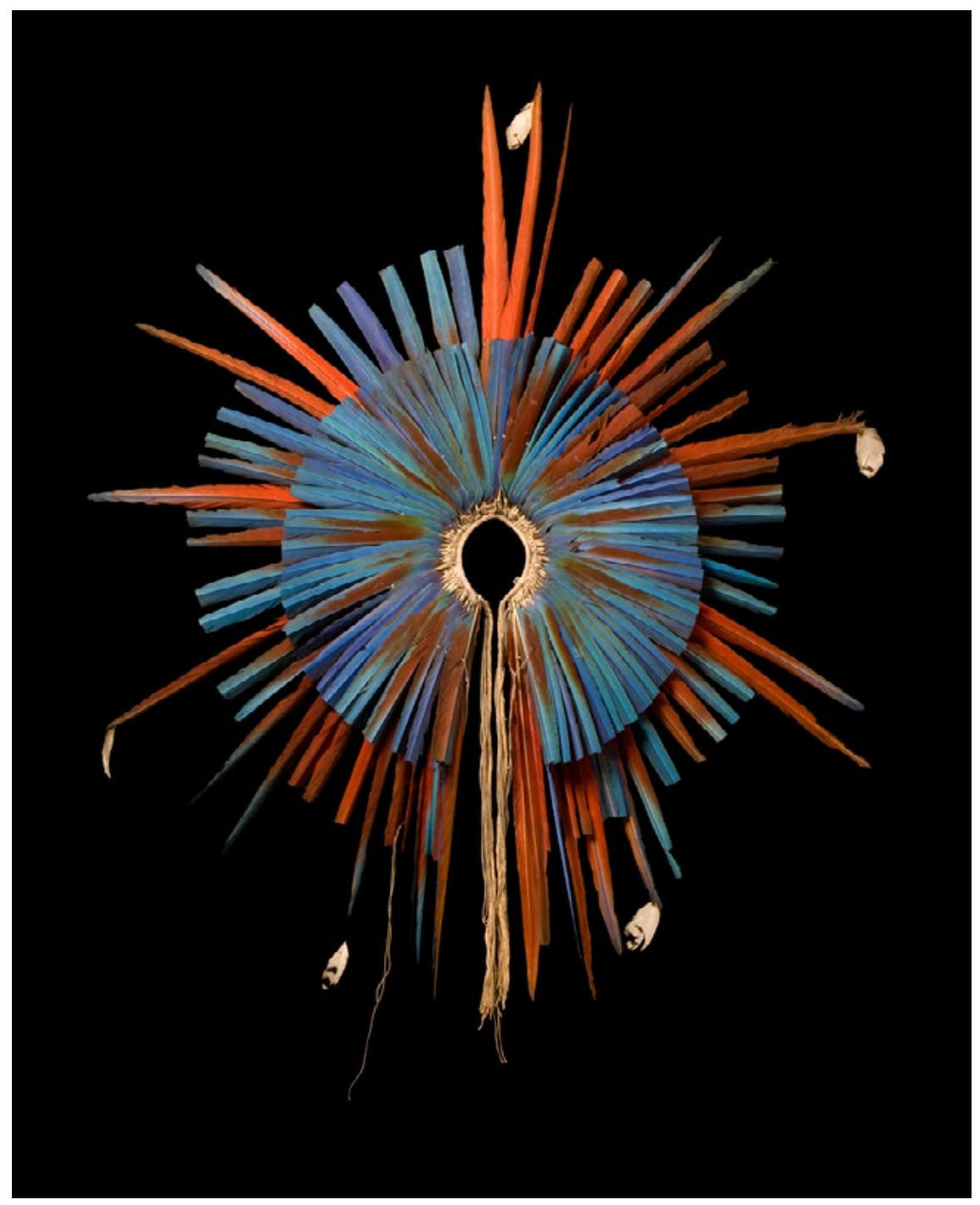

Large occipital circular headpiece (Àkparidjê rajx) 


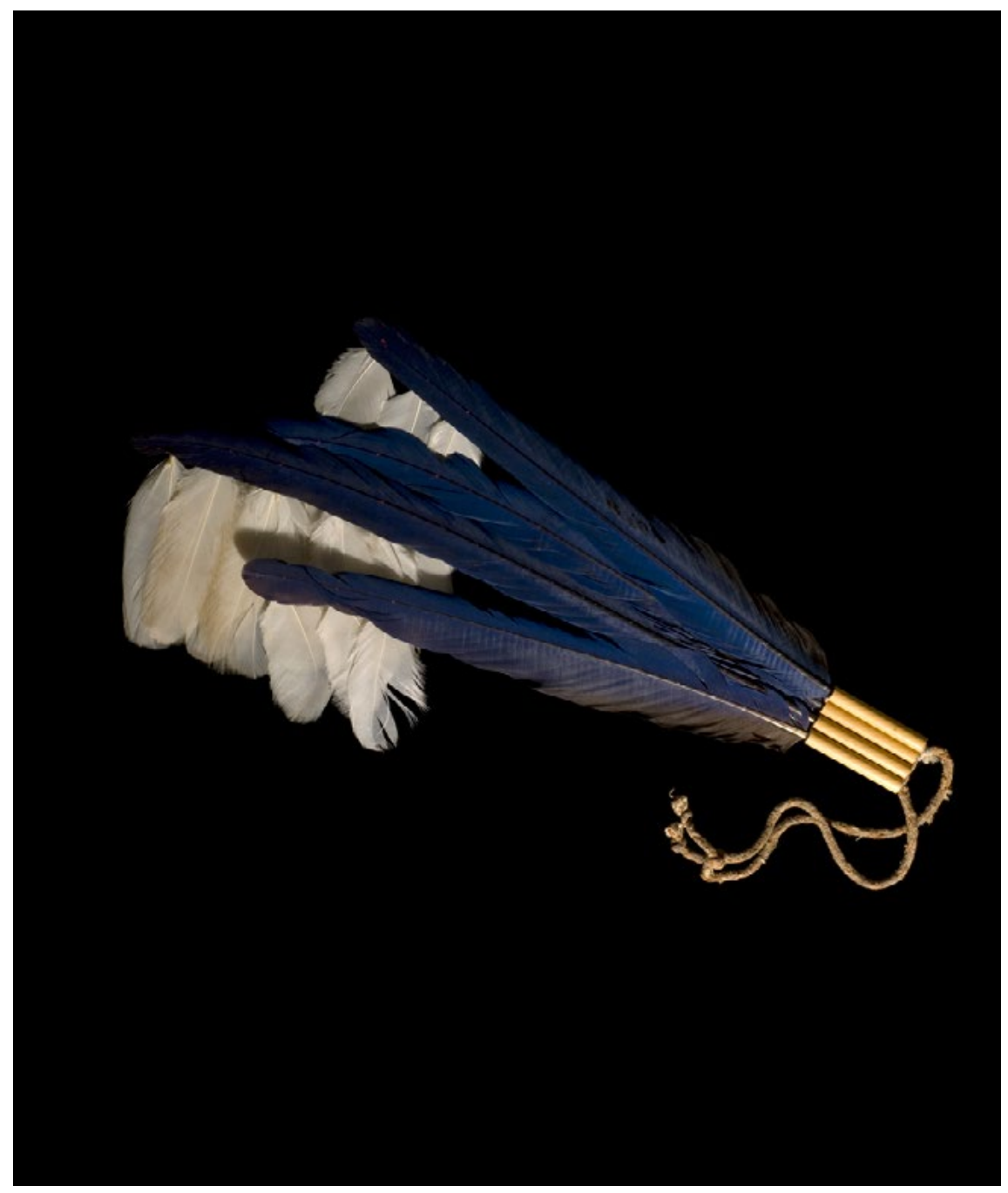

Dorsal pendent made from Macaw feathers (Màt jamy jakrô) 


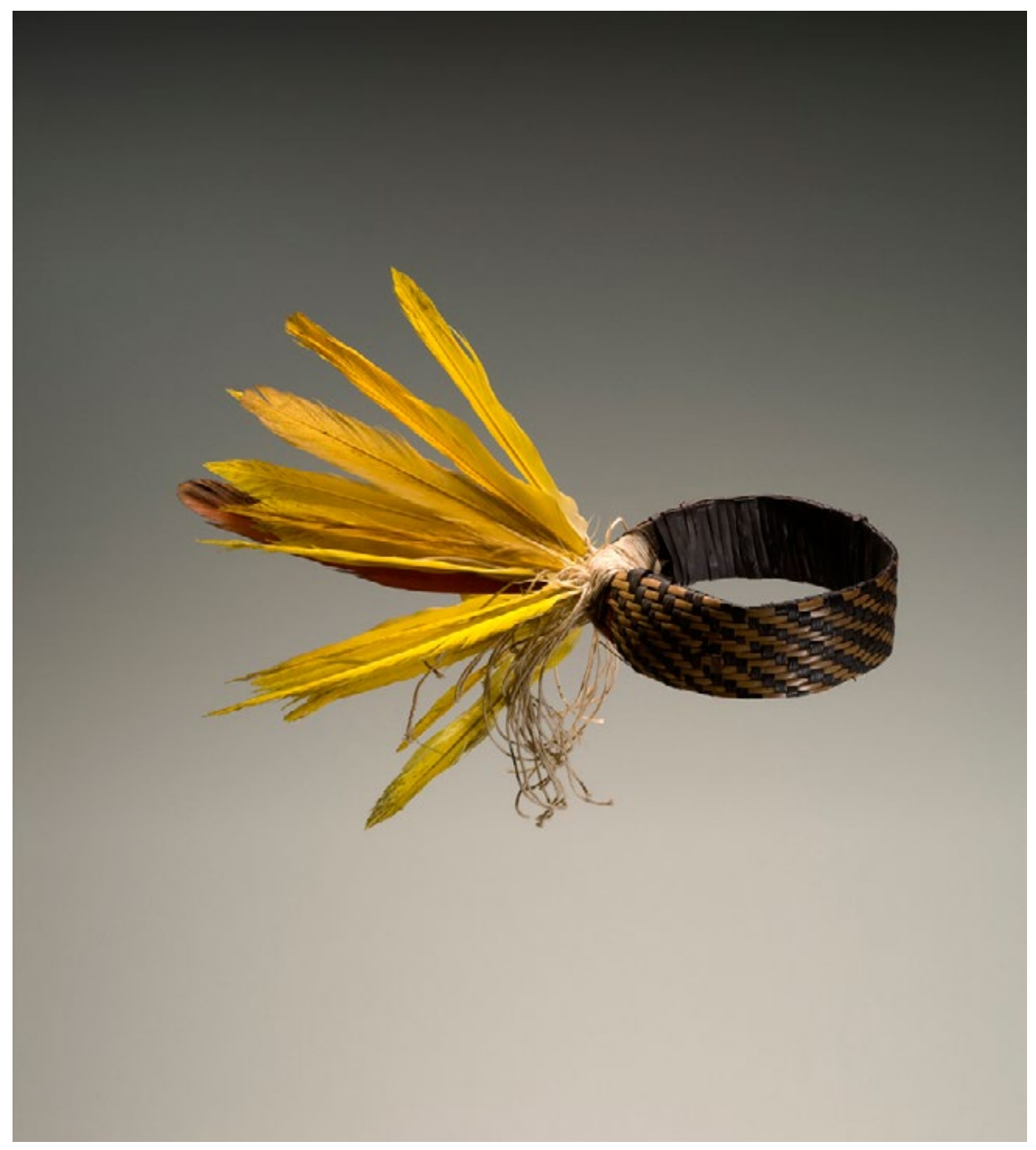

Armbard of woven feathers (Padjê kajêti pin kà kam yry) 


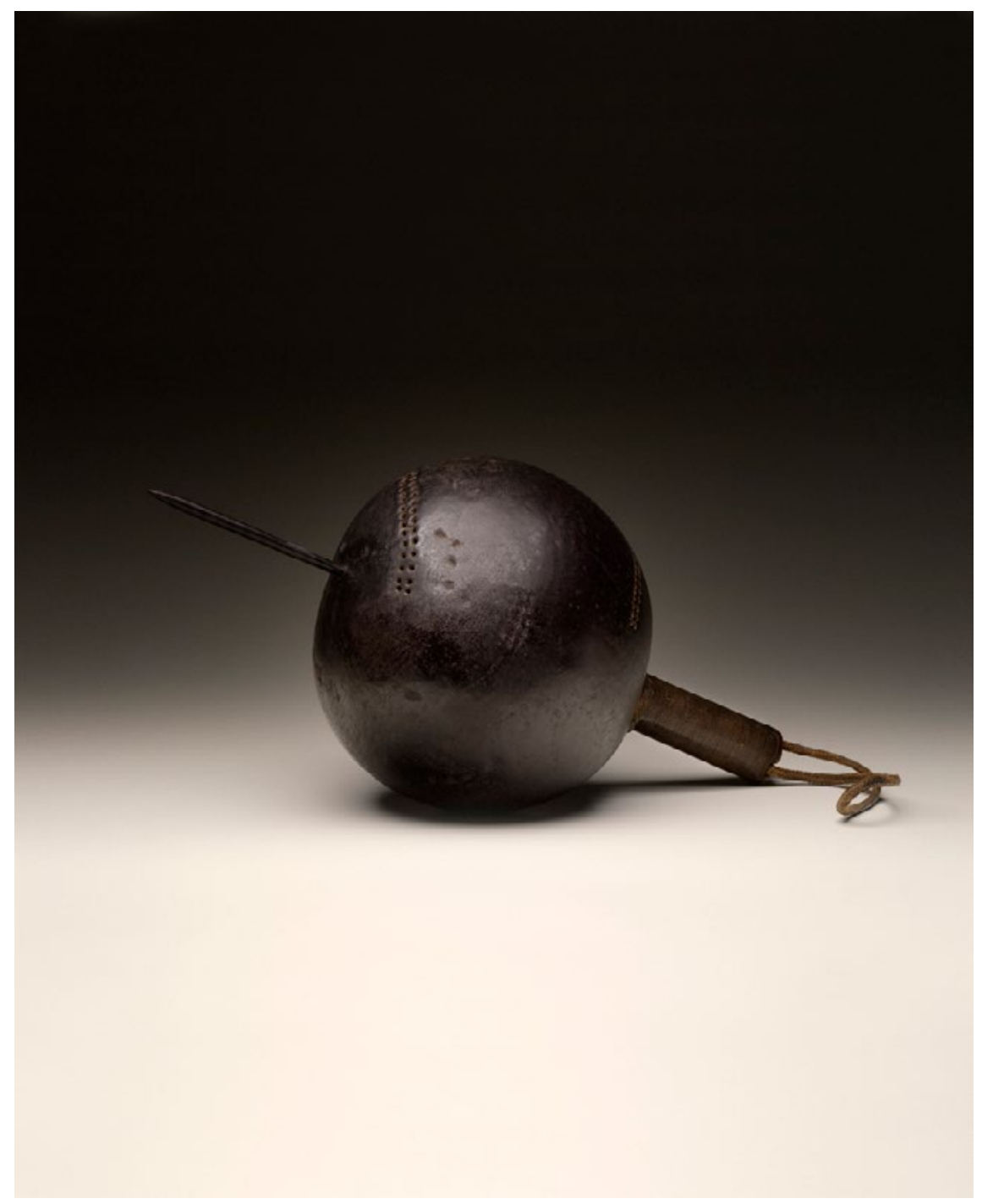

Case for feathers (Potikpu) 


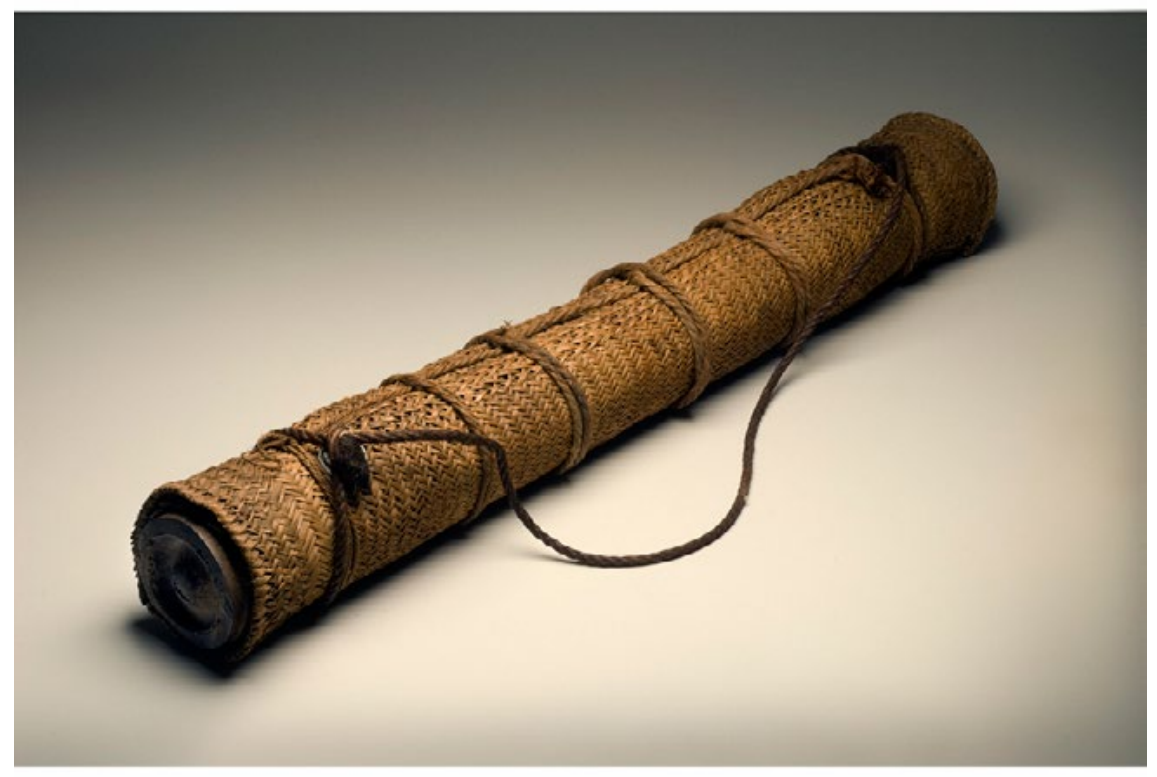

Globe-shaped maraca rattle (Ngôkon) 


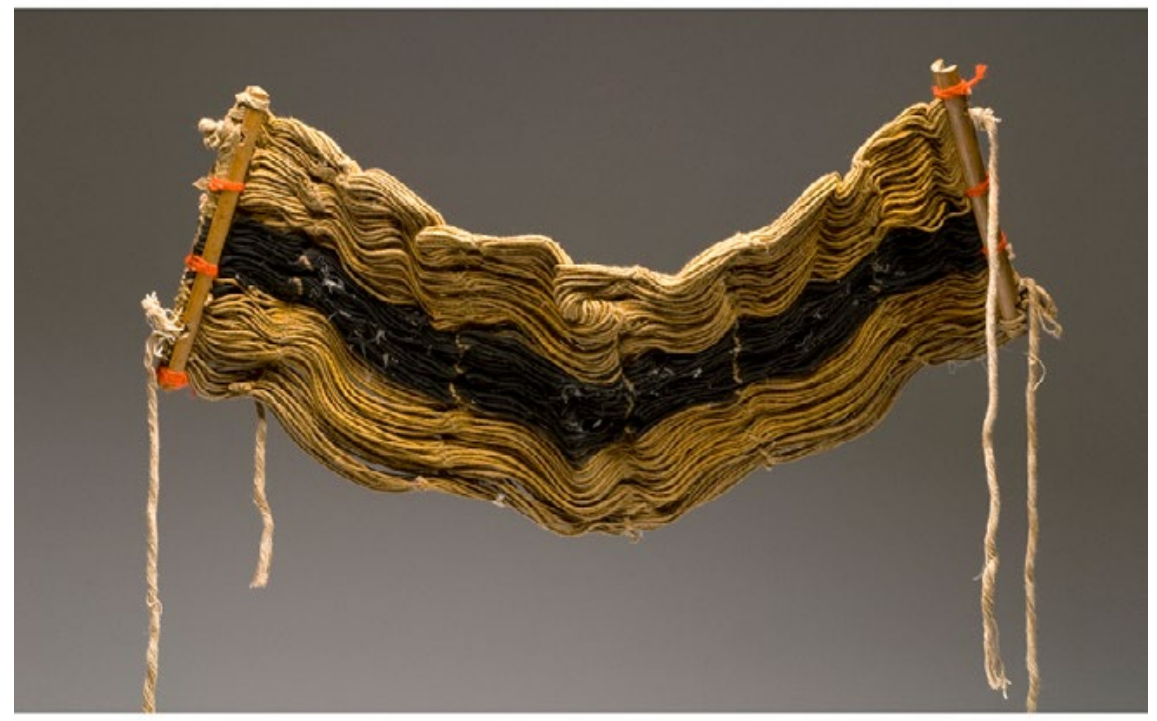

Rope belt (Ãpredjà) 


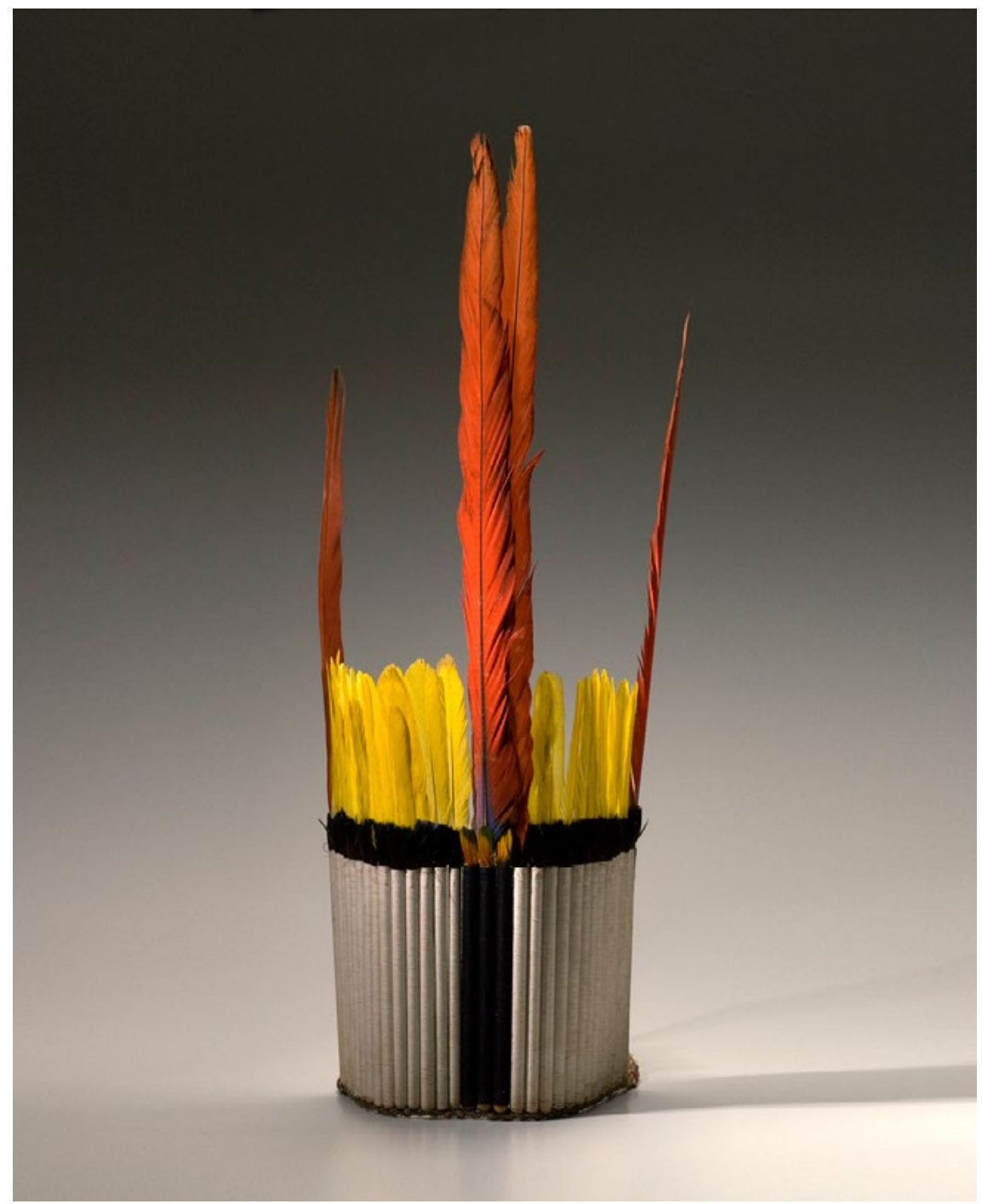

Vertical headdress (Kruapu) 


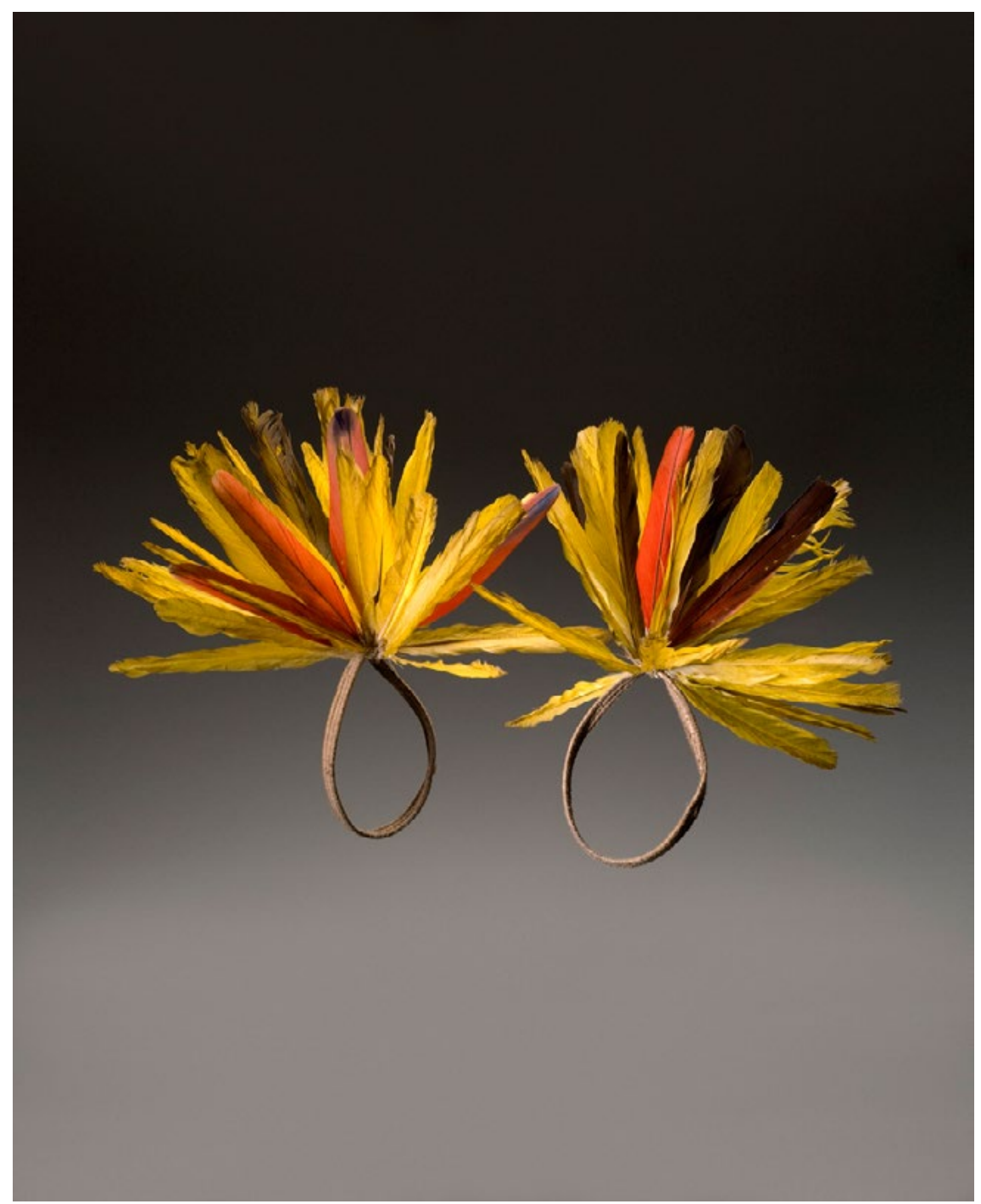

Feathered armbands (Padjê kajêti) 


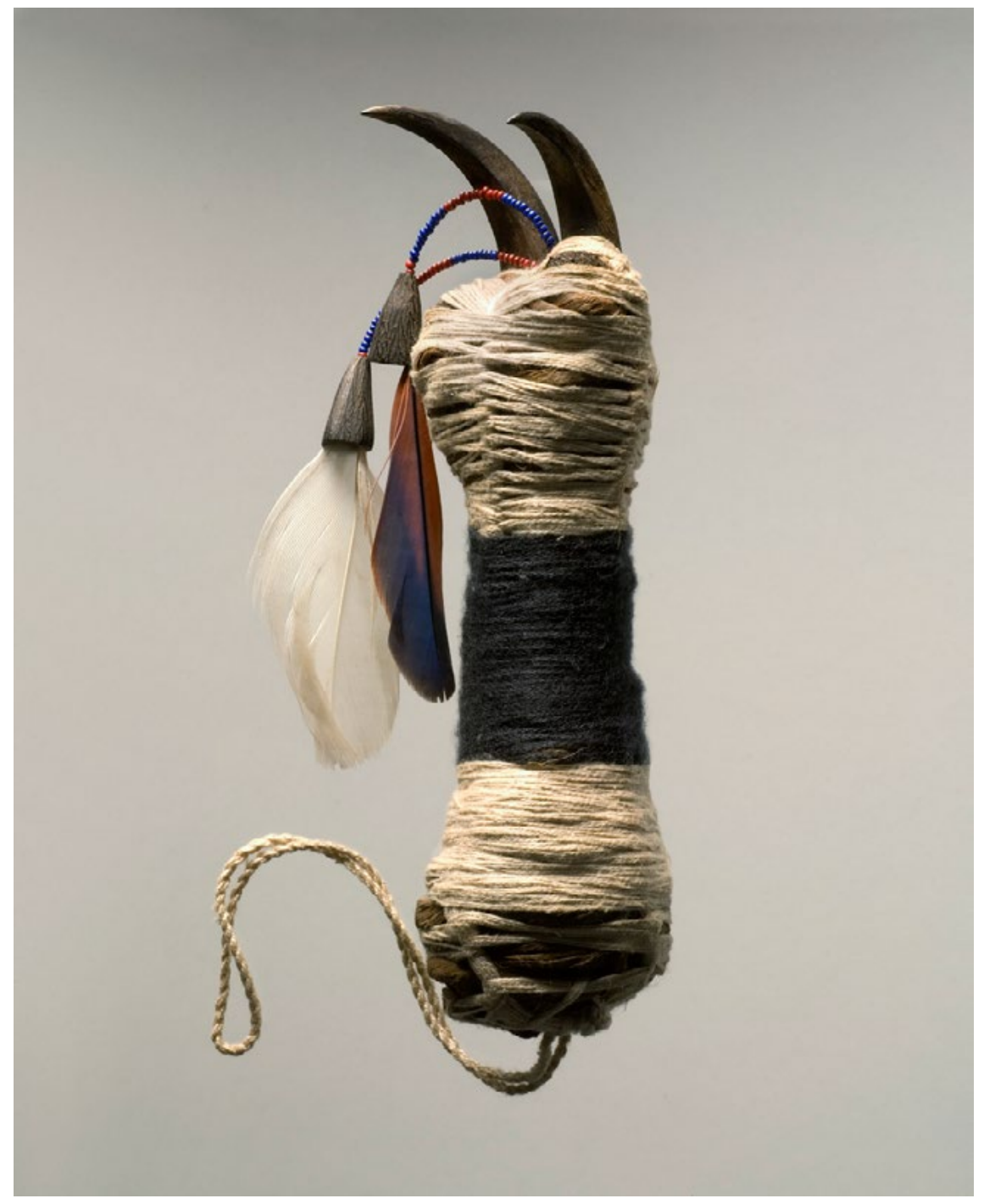

Scarifying equipment (Djwa) 


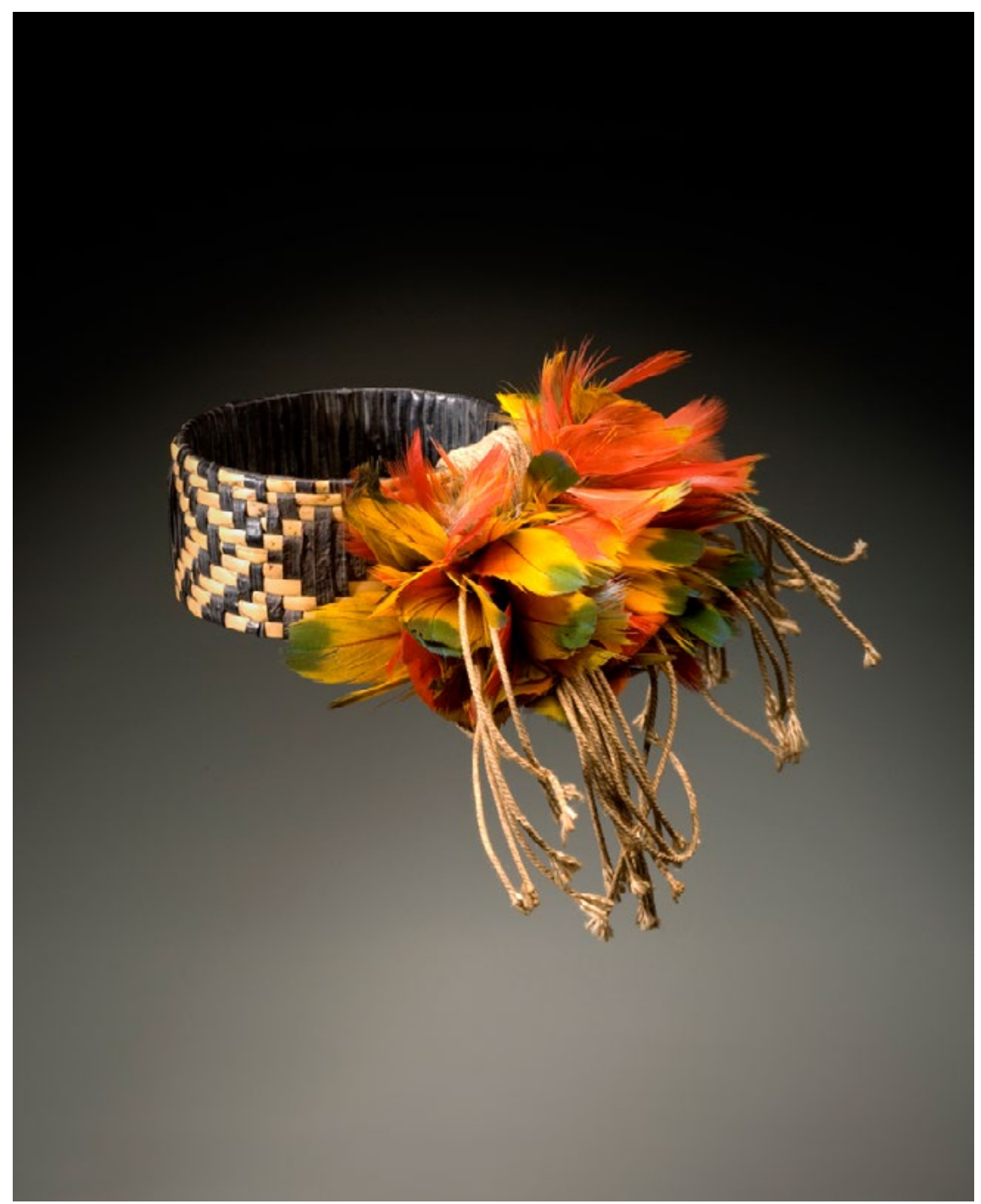

Feather armband woven with a snake motif (Padjê krã kangati'ôk) 


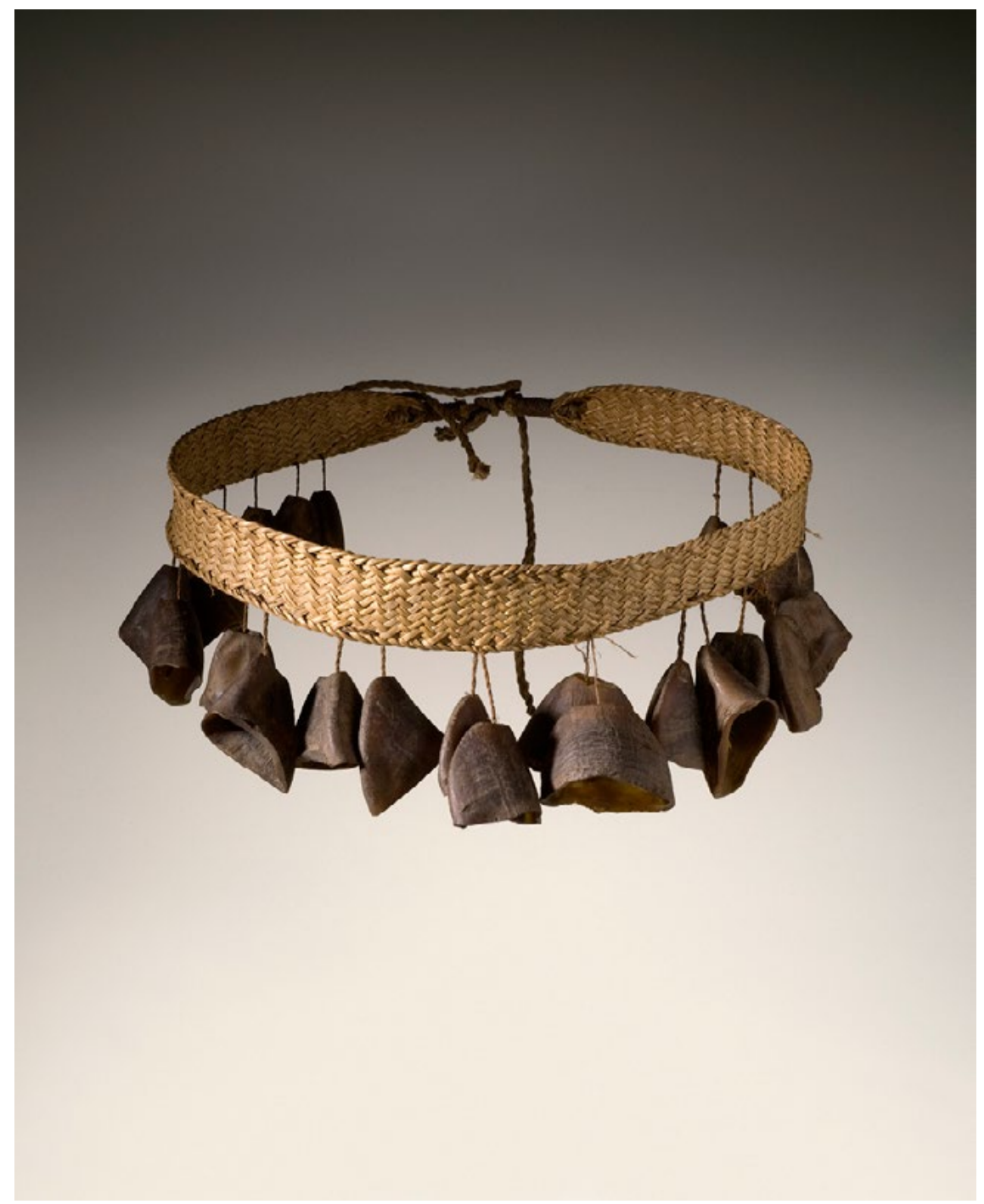

Rattling belt made with tapir claws (Kraj predjà mry nhy ty) 


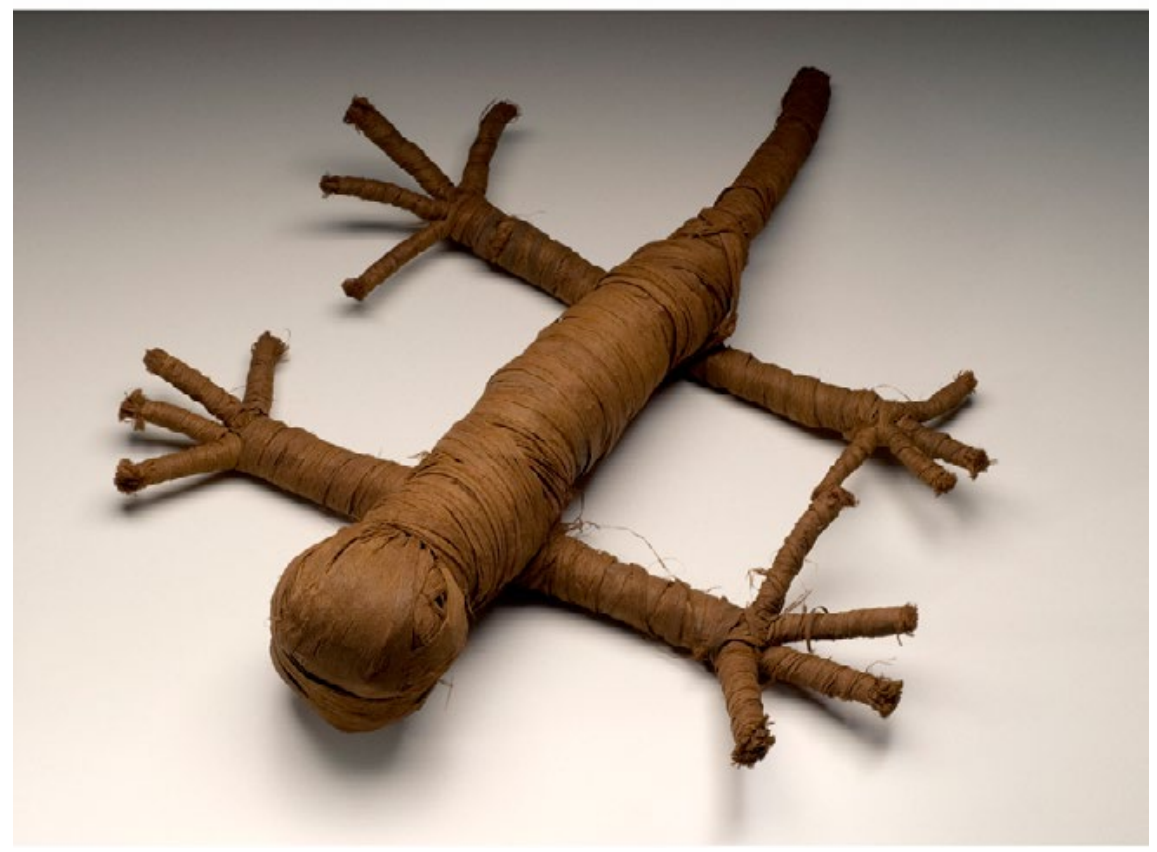

Woven zoomorphic toy with a monkey motif (Kukonh karon) 


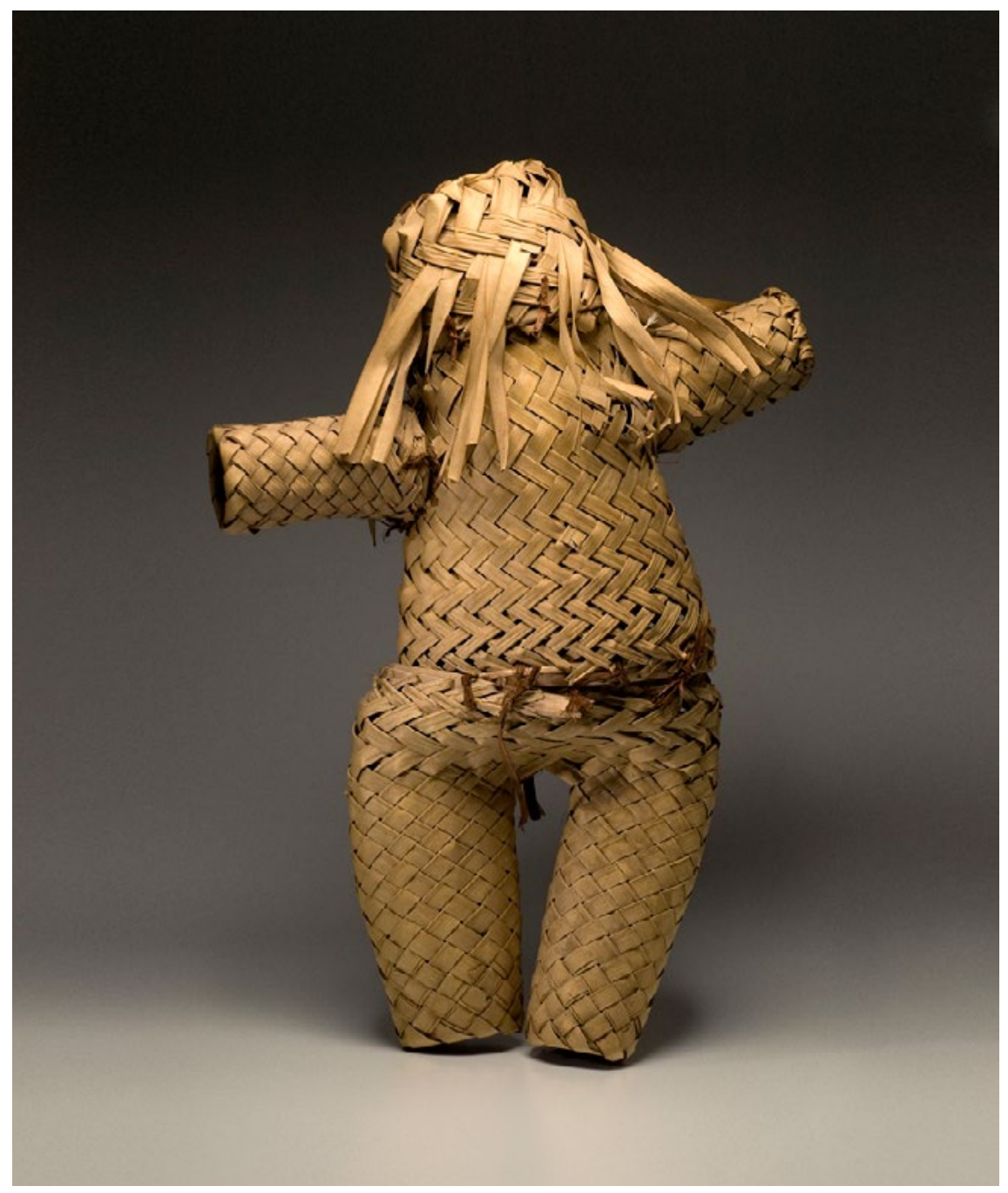

Anthropomorphic mask toy (Mekaron) 


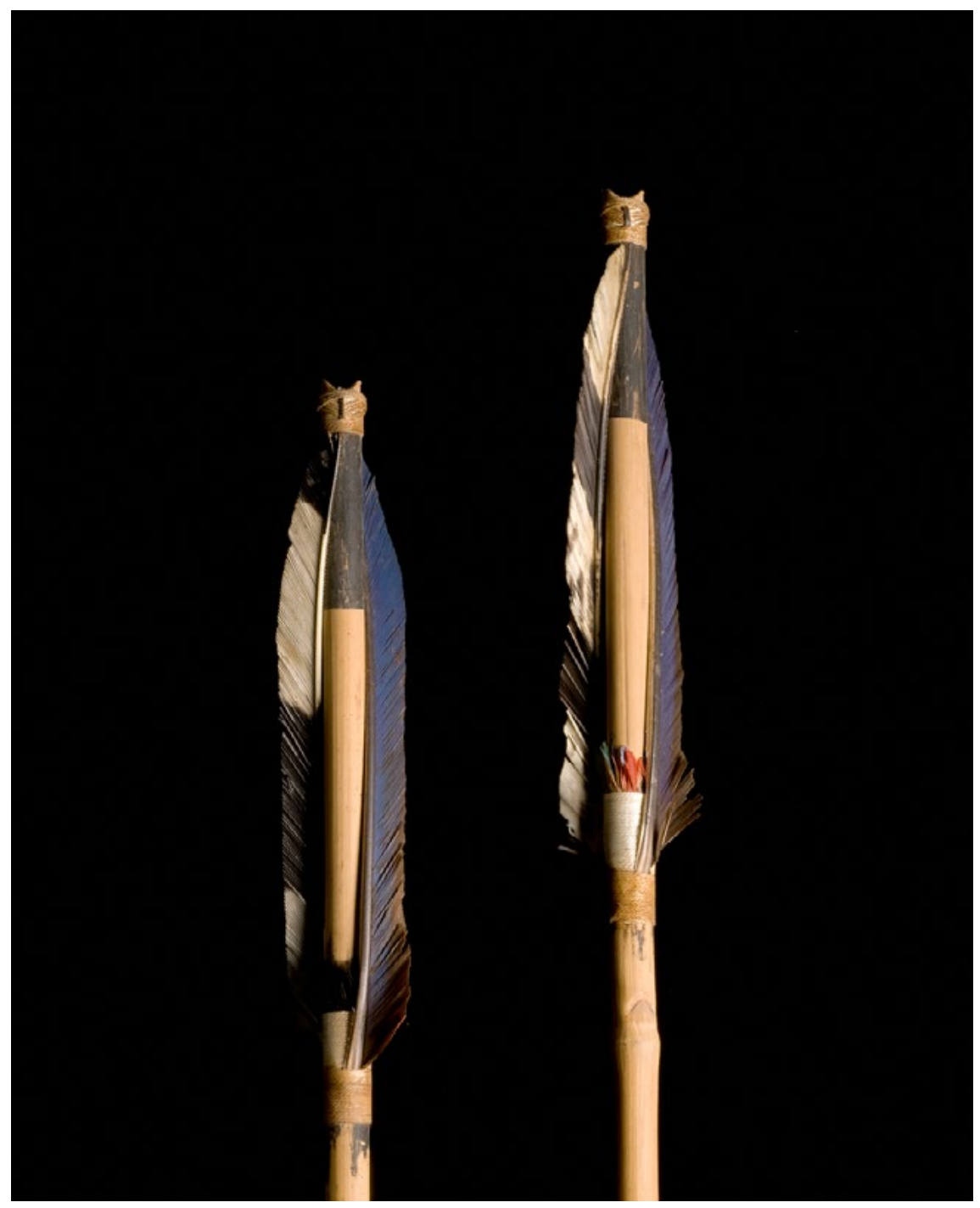

Shaft of a feathered arrow (Buri) 


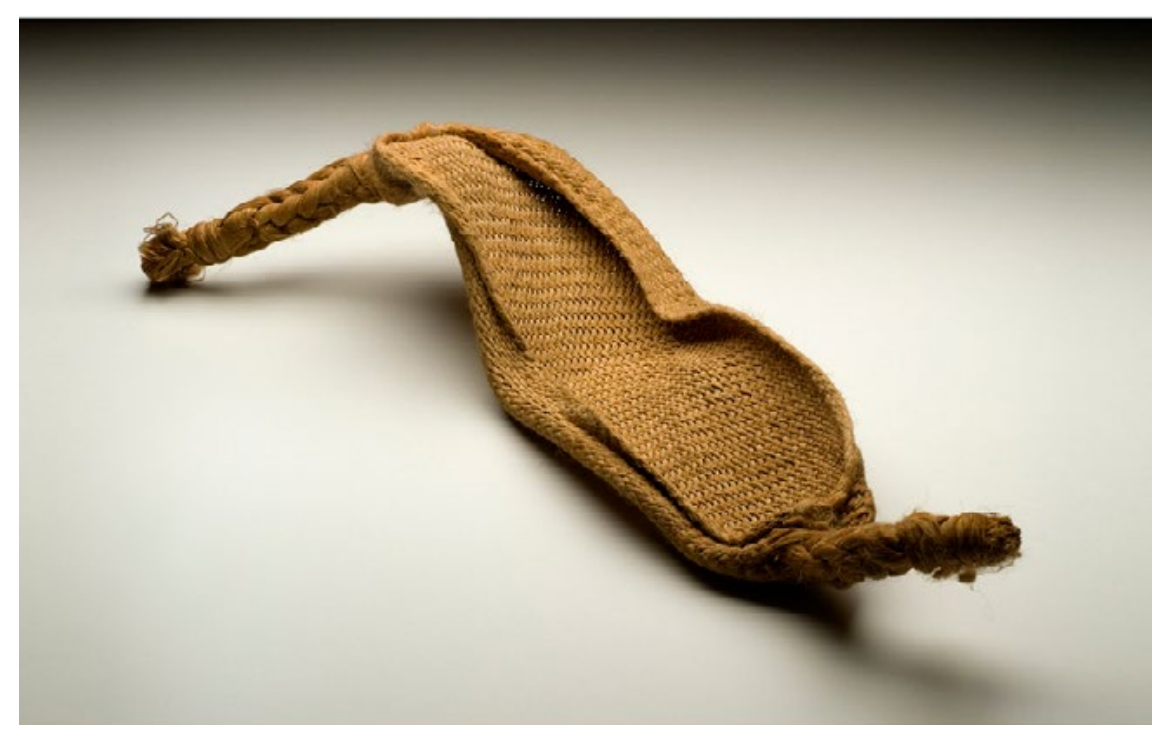

Tipití (Krin'ô) 


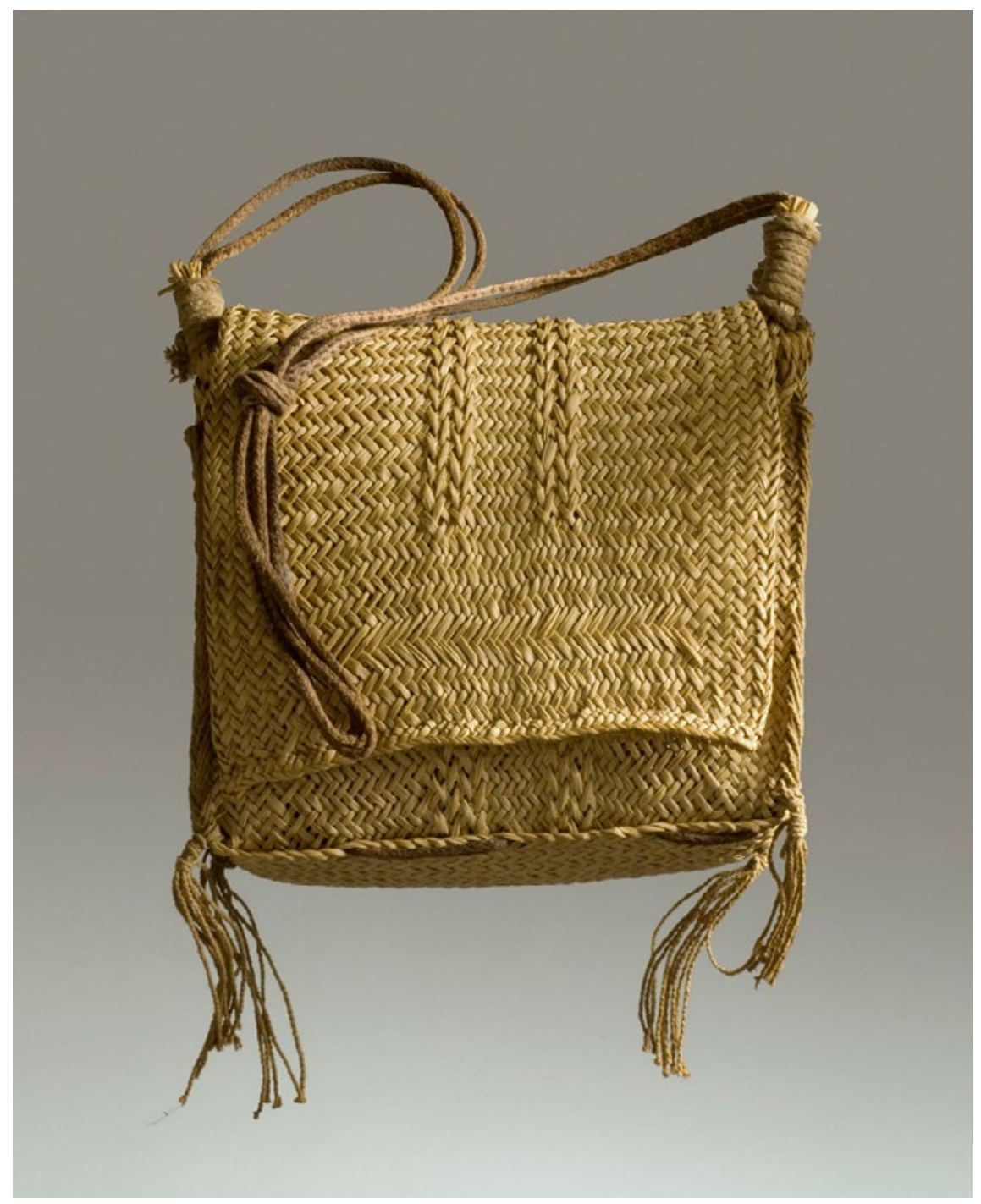

Bag-like basket (Mokà) 


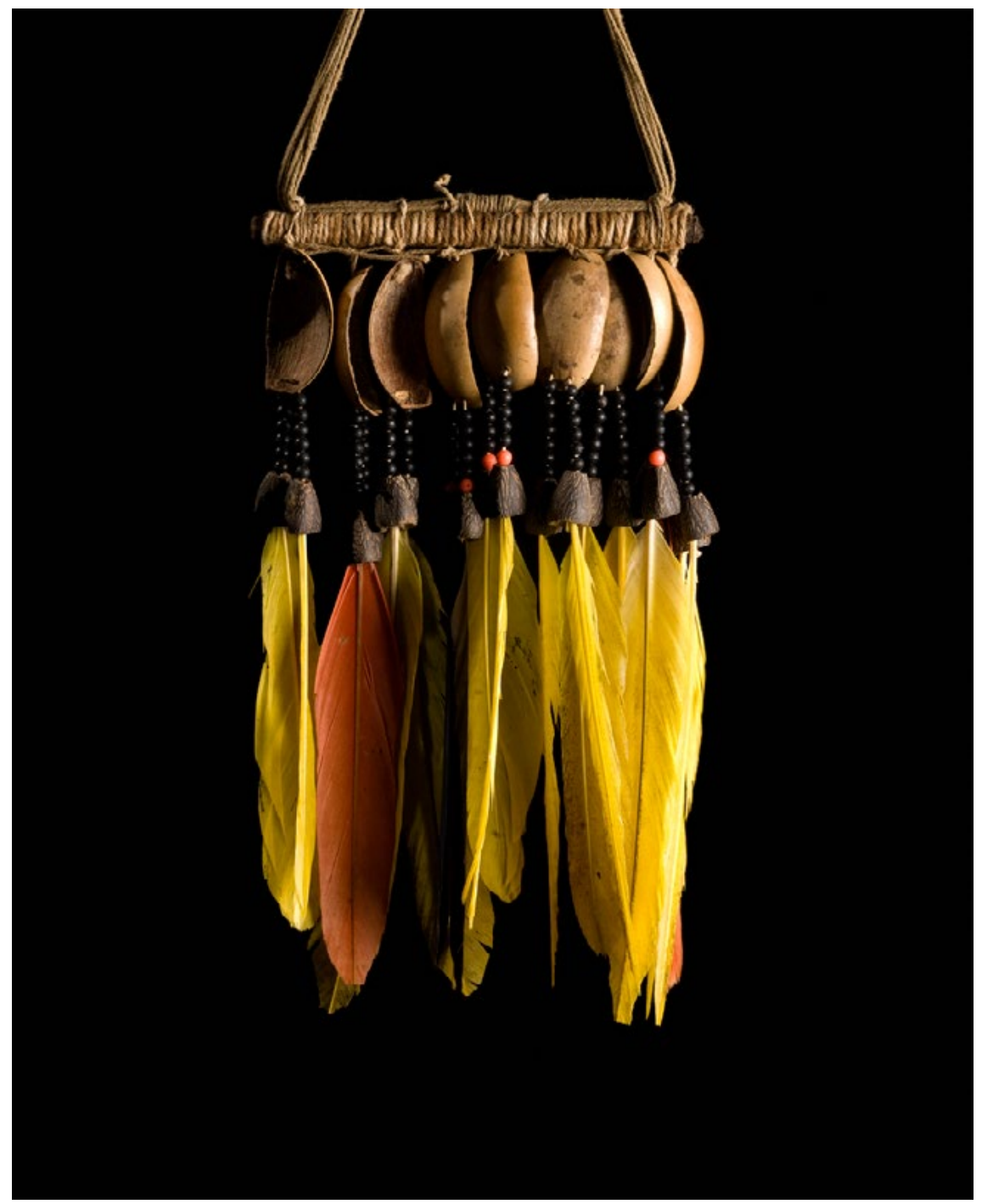

Bandolier with feathers and fruit seeds (Kamôkti arapê jabu) 


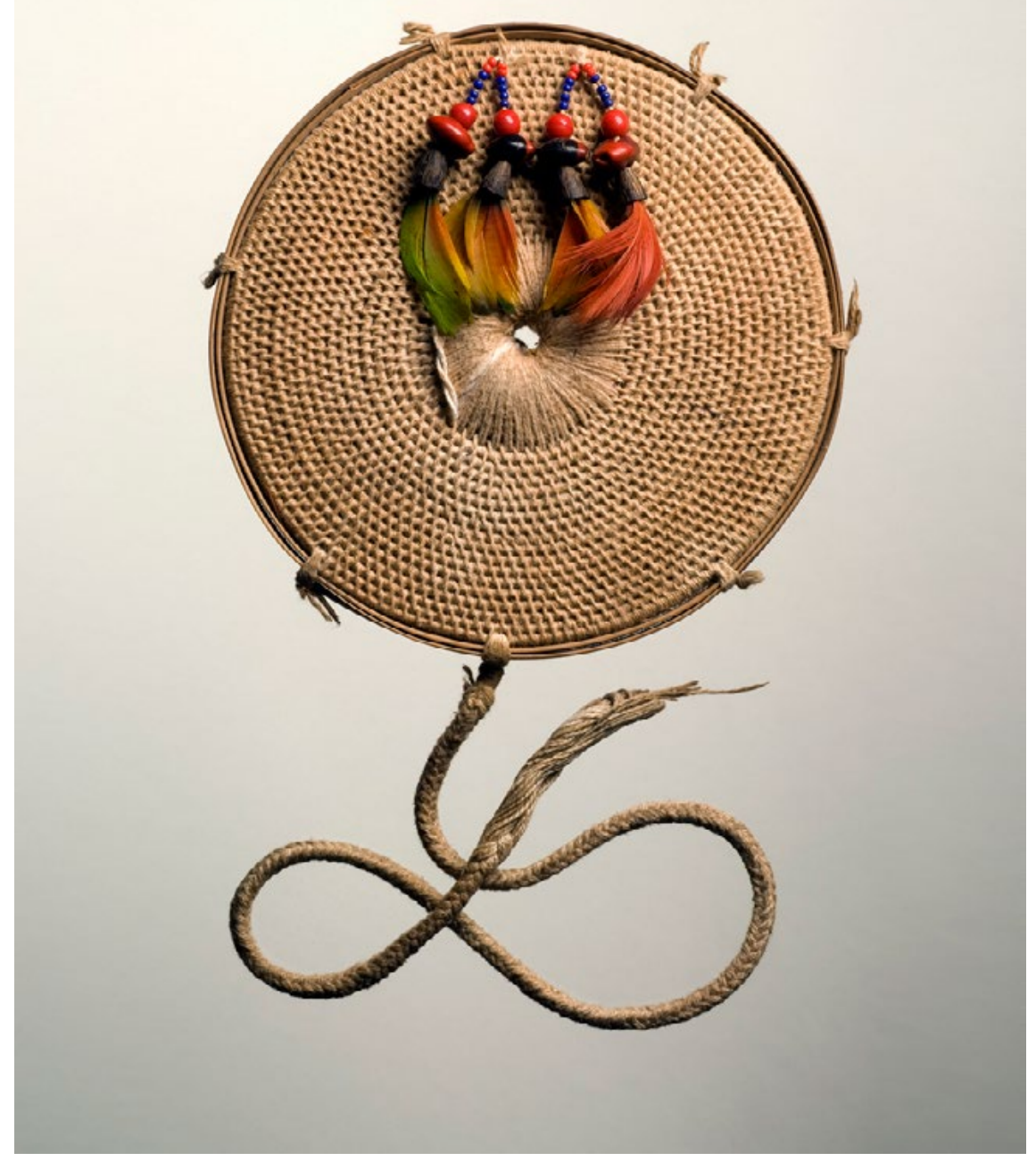

Occipital disc for headdress (Kêjkry) 


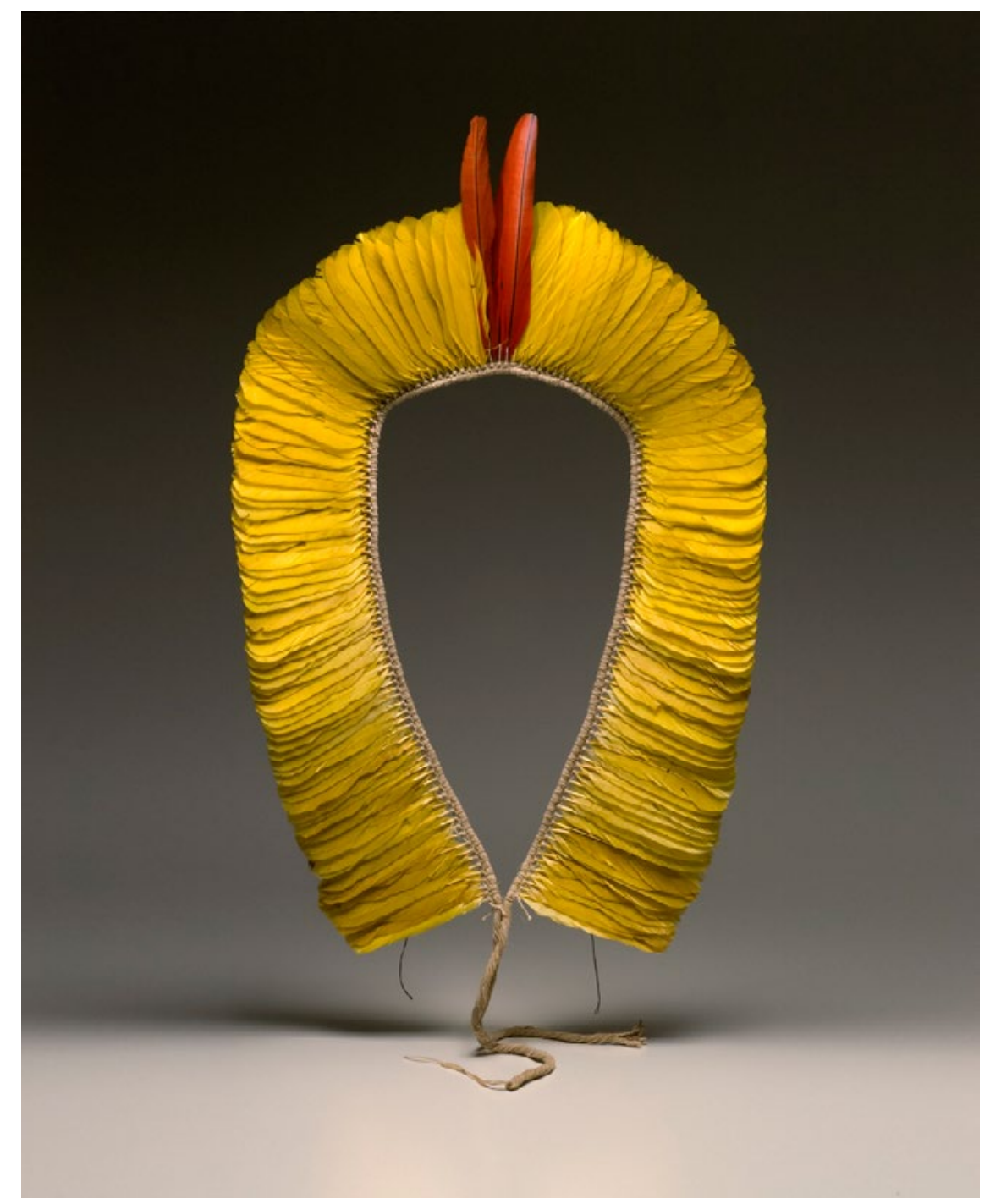

Vanity set with Oropendola [japu] feathers (Pejàti jamy meàkà) 


\section{References}

ABREU, Regina. M. 2008. “A emergência do 'outro' no campo do patrimônio cultural”. Revista do Museu de Arqueologia e Etnologia, Suplemento, 7: 9-20.

ABREU, Regina. 2005. "Museus etnográficos e práticas de colecionamento: antropofagia dos sentidos". Revista do Patrimônio Histórico e Artístico Nacional, 31: 101-125.

APPADURAI, Arjun. (ed.). 1986. The social life of things: commodities in cultural perspective. Cambridge: Cambridge University Press.

BARCELOS NETO, Aristóteles. 2006. Com os índios wauja. Objectos e personagens de uma coleção amazônica. Lisboa: Museu Nacional de Etnologia.

BELK, Russel. W. 1999. “Collectors and collecting”. In: S. Pearce (ed.). Interpreting objects and collections. London: Routledge. pp. 317-326.

BOLTON, Lissant 2003. "The object in view: aborígenes, melanesians, and museums”. In: A. Peers\& A. K. Brown (eds.). 2003. Museums and source communities: a Routledge reader. London/New York: Routledge. pp. 42-54.

BROEKHOVEN, Laura V.; BUIJS, Cunera \& HOVENS, Pieter (eds.). 2010. Sharing knowledge e cultural heritage. First nations of the Americas. Studies in collaboration with indigenous peoples from Greenland and South America. Leiden: Sidestone Press.

CHIARA, Vilma. 1986. "Armas: bases para uma classificação". In: D. Ribeiro (ed.). Suma etnológica brasileira. Petrópolis: Vozes. vol. 2. pp. 117-137.

CHIARA, Vilma. \& HEATH, Ernest G. (eds.). 1978. Brazilian indian archery: a preliminary ethno-taxological study of the archery of brazilian indians. England: The Simon Archery Foundation.

COLLIER, D. \& TSCHOPIK JR., H. S. 2003. "The role of museums in american anthropology”. In: Nash \& Feinman (eds.). 2003. Curators, collections and contexts: anthropology at the field museum, 1893-2002. Chicago: Field Museum of Natural History. pp. 23-30.

COHN, Clarice. 2000. A criança indígena: a concepção xikrin de infância e aprendizado. Master's dissertation in Social Anthropology, Faculdade de Filosofia, Letras e Ciências Humanas, Universidade de São Paulo, São Paulo, FFLCH-USP.

CRUIKSHANK, Julie. 1998. The social life of stories. Narrative and knowledge in the Yukon territory. Lincoln/London: University of Nebraska Press.

FABIAN, Johannes. 2004. "On recognizing things: the 'ethnic artefact' and the 'ethnographic object'”, L'Homme, Dossier Espèces d'Objets, 170: 47-61. 
FABIAN, Johannes. 2010. "Colecionando pensamentos: sobre o ato de colecionar". Mana. Estudos de Antropologia Social, 16(1): 59-73.

FERREIRA, Lúcio M. 2010. Território primitivo. A institucionalização da arqueologia no Brasil (1870-1917). Porto Alegre: EDIPUCRS.

FERREIRA, Lúcio M.; NOELLI, Francisco S. 2009. “João Barbosa Rodrigues: precursor da etnoclassificação na arqueologia amazônica”. Amazônica Revista de Antropologia, 1(1): 68-95.

FIENUP-RIORDAN, Ann 2003. "Yup'ik elders in museums: fieldwork turned on its head". In: A. Peers\& A. K. Brown (eds.). 2003. Museums and source communities: a Routledge reader. London/New York: Routledge. pp. 28-41.

FORMANECK, Ruth 1999. "Why they collect: collectors reveal their motivations". In: S. Pearce (ed.), Interpreting objects and collections. London: Routledge. pp. 327-335.

FOWLER. 2003. "A natural history of man: reflections on anthropology. Museums and science”. In: Nash \& Feinman (eds.), Curators, collections and contexts: anthropology at the Field Museum, 1893-2002. Chicago: Field Museum of Natural History. pp. 11-22.

FRIKEL, Protásio 1968. Os Xikrin: equipamentos e técnicas de subsistência. Publicações Avulsas do Museu Goeldi, 7 117p. [é um livro, que saiu como volume 7 da coleção do Museu Goeldi]]

GALLOIS, Dominique 2006. Patrimônio cultural imaterial e povos indígenas. São Paulo: IEPÉ. 1eed.

GELL, Alfred. 1998. Art and agency. Oxford: Clarendon Press.

GIANINI, Isabelle V. 1991. A ave resgatada: a impossibilidade da leveza do ser. Master's Dissertation in Social Anthropology Social, Faculdade de Filosofia, Letras e Ciências Humanas, Universidade de São Paulo, São Paulo, FFLCH-USP.

GONÇALVES, José Reginaldo. 2005. "Antropologia dos objetos: coleções, museus e patrimônios”. BIB: Revista Brasileira de Informação Bibliográfica em Ciências Sociais, 6o: 7-26.

GORDON, Cesar. 2003. Folhas pálidas: a incorporação Xikrin (Mebengokre) do dinheiro e das mercadorias. Doctoral Thesis in Social Anthropology, Museu Nacional, UFRJ, Rio de Janeiro, PPGAS-MN.

GORDON, Cesar. 2006. Economia selvagem: ritual e mercadoria entre os índios Xikrin Mebêngôkre. São Paulo: Edunesp / Instituto Socioambiental / NuTI. GORDON, Cesar. 2011. "Em nome do belo: o valor das coisas xikrin-mebêngôkre". 
In: F. Silva\& C. Gordon (orgs), Xikrin: uma coleção etnográfica. São Paulo: EdUSP. pp. 207-262.

GORDON, Cesar \& SILVA, Fabíola. 2005. "Objetos vivos: a curadoria da coleção etnográfica Xikrin-Kayapó no Museu de Arqueologia e Etnologia - MAE/USP”. Revista Estudos Históricos, 36: 93-110.

GRUPIONI, Luís. D. 1998. Coleções e expedições vigiadas; os etnólogos no Conselho de Fiscalização das Expedições Artísticas e Científicas no Brasil. São Paulo: HUCITEC/ANPOCS.

HALLAM, Elizabeth 2000. “Texts, objects and 'otherness': problems of historical process in writing and displaying cultures”. In: E. Hallam \& B. Street (eds.). 2000. Cultural encounters. Representing otherness. London/New York: Routledge. pp. 260-283.

HALLAM, Elizabeth \& STREET, Brian (eds.). 200o. Cultural encounters. Representing otherness. London/New York: Routledge.

HENARE, Amiria; HOLBRAAD, Martin e WASTEL, Sari (Eds). 2006. Thinking through things: theorising artefacts ethnographically. New York: Routledge.

KODAMA, Kaori. 2009. Os índios no Império do Brasil. A etnografia do IHGB entre as décadas de 1840 e 1860. São Paulo/Rio de Janeiro: EDUSP/Editora FIOCRUZ.

KUPER, Adam. 1973. Anthropology and anthropologists: the modern British School. London: Routledge.

MILLER, Daniel. 1987. Material cultures and mass consumption. Oxford: Blackwell.

MILLER, Daniel. 2005. Materiality. Durham: Duke University Press.

MYERS, Fred (ed.). 2001. The empire of things: regimes of value and material culture. Sante Fe: School of American Research Press.

NASH, Stephen \& FEINMAN, Gari (eds.). 2003. Curators, collections and contexts: anthropology at the Field Museum, 1893-2002.(Fieldiana Anthropology, n.s. 36). Chicago: Field Museum of Natural History. páginas????.[é um livro]

NICKS, Trudy 2003. "Introduction”. In: A. Peers \& A. K. Brown (eds.), Museums and source communities: a Routledge reader. London/New York: Routledge. pp. 19-27.

PAES, Francisco S. 2006. Os modelos da experiência ou a experiência dos modelos: introdução ao estudo do cerimonial xikrin. Master's Dissertation in Social Anthropology, Faculdade de Filosofia, Letras e Ciências Humanas, 
Universidade de São Paulo, São Paulo, FFLCH-USP.

PASZTORY, Esther. 2005. Thinking with things: toward a new vision of art.

Austin: University of Texas Press.

PATTERSON, Thomas. 2001. A social history of anthropology in the US. Oxford: Berg.

PEARCE, Susan (ed.). 1999. Interpreting objects and collections. London: Routledge.

PEARCE, Susan (ed.). 1999a. “Museums objects”. In: Susan Pearce (ed.). 1999. Interpreting objects and collections. London: Routledge. pp. 9-11.

PEARCE, Susan (ed.). 1999b. "Objects as meaning; or narrating the past". In: Susan Pearce (ed.). 1999. Interpreting objects and collections. London: Routledge. pp. 19-29.

PEERS, Laura \& BROWN, Alison K. (eds.). 2003. Museums and source communities: a Routledge reader. London/New York: Routledge.

PEERS, Laura \& BROWN, Alison K. (eds.). 2003. "Introduction”. In: A. Peers \& A. K. Brown (eds.), Museums and source communities: a Routledge reader. London/New York: Routledge. pp. 1-16.

PROWN, Jules 1999. "Mind in matter: an introduction to material culture theory and method". In: S. Pearce (ed.), Interpreting objects and collections. London: Routledge. pp. 133-138.

RIBEIRO, Berta G. \& VAN VELTHEM, Lúcia H. 1998. “Coleções etnográficas: documentos materiais para a história e a etnologia”. In: M. Carneiro da Cunha (org.), História dos índios no Brasil. São Paulo: Companhia das Letras. pp. 103-112.

RIBEIRO, Berta G. 1980. A civilização da palha. Doctoral thesis in Social Anthropology, Universidade de São Paulo.

RIBEIRO, Berta G. 1985. A arte do trançado dos índios do Brasil. Um estudo taxonômico. Belém: Museu Paraense Emílio Goeldi.

RIBEIRO, Berta G. 1988. Dicionário do artesanato indígena. São Paulo: Itatiaia.

RIBEIRO, Berta G. 1987. "Bases para uma classificação dos adornos plumários dos indios do Brasil”. In: Berta Ribeiro (coord.), Suma etnológica brasileira (arte índia). Petrópolis: Vozes/FINEP. pp. 59-119.

SANTOS GRANERO, Fernando. (ed.). 2009. The occult life of things: native amazonian theories of materiality and personhood. Tucson: The University of Arizona Press.

SHELTON, Anthony 200o. "Museum ethnography: an imperial science”. In: 
E. Hallam \& B. Street (eds.), Cultural encounters. Representing otherness. London/New York: Routledge. pp. 155-193.

SILVA, Fabíola A. 2000. As tecnologias e seus significados: um estudo da cerâmica dos Assurini do Xingu e da cestaria dos Kayapó-Xikrin sob uma perspectiva etnoarqueológica. Doctoral Thesis in Social Anthropology, Faculdade de Filosofia, Letras e Ciências Humanas, Universidade de São Paulo, São Paulo, FFLCH-USP.

SILVA, Fabíola A. \& GORDON, Cesar (orgs.); SOUZA E SILVA, Wagner (photographs). 2011. Xikrin: uma coleção etnográfica. São Paulo: Edusp. SILVA, Fabíola A. \& GORDON, Cesar. 2011a. “Objetos vivos: a curadoria da coleção etnográfica Xikrin”. In: Xikrin: uma coleção etnográfica. São Paulo: Edusp. pp. 17-26.

SILVA, Fabíola A. \& GORDON, Cesar. 2011b. "Histórias de uma coleção indisciplinada: depoimento de Lux Vidal a Fabíola Andréa Silva e Cesar Gordon”. In: Xikrin: uma coleção etnográfica. São Paulo: Edusp. pp. 37-58.

STOCKING Jr., George. 1976. "Ideas and institutions in american anthropology: toward a history of the interwar period”. In: G. Stocking (ed.), Selected papers from the american anthropologist, 1921-1945. Washington DC: American Anthropological Association. pp. 1-42.

THOMAS, Nicholas. 1991. Entangled objects: exchange, material culture and colonialism in the Pacific. Cambridge, Mass.: Harvard University Press.

VAN VELTHEM, Lúcia H. 1998. A pele do Tuluperê. Belém: Museu Paraense Emílio Goeldi.

VAN VELTHEM, Lúcia H. 2012. "O objeto etnográfico é irredutivel? Pistas sobre novos sentidos e análises”. Boletim do Museu Paraense Emilio Goeldi. Ciências Humanas, 7(1): 51-66.

VIDAL, Lux B. 1977. Morte e vida de uma sociedade indígena brasileira: os Kayapó do rio Cateté. São Paulo: HUCITEC/EDUSP.

VIDAL, Lux B. 2008. "O museu dos povos indígenas do Oiapoque Kuahí: gestão do patrimônio cultural pelos povos indígenas do Oiapoque, Amapá”. Revista do Museu de Arqueologia e Etnologia, Suplemento, 7: 109-115. 